\title{
24. BENTHIC FORAMINIFERS AND PALEOBATHYMETRY OF THE JAPAN TRENCH AREA, LEG 57, DEEP SEA DRILLING PROJECT
}

\author{
Gerta Keller, School of Earth Sciences, Stanford University, Stanford, California
}

\begin{abstract}
Deep sea drilling in the Japan Trench area recovered a Late Cretaceous to Pleistocene sedimentary and biostratigraphic record unraveling the tectonic and paleobathymetric history of the convergent margin. Benthic foraminiferal assemblages spanning the Late Cretaceous to the late Pleistocene permit reconstruction of the paleobathymetric history of this area. During the Late Cretaceous a deep bathyal environment persisted, characterized by deposition of finegrained turbidites. Sometime during the early Paleogene, uplift occurred, followed by erosion and deposition of a conglomerate which presumably derived from a nearby volcanic source. A shallow marine sequence consisting of a massive sandstone marked by shallow-water benthic foraminifers, gastropods, and pelecypods was deposited in the late Oligocene. During the early Miocene a fine-grained turbidite-claystone was deposited on a subsiding slope which reached upper middle bathyal depth. Subsidence continued throughout the Miocene and reached lower bathyal depths $(2000 \mathrm{~m}+)$ by the late Miocene, accompanied by deposition of a thick hemipelagic sequence. The same depositional environment persisted through the early Pliocene. A gradual shoaling from 2000 meters + to 1500 meters (present depth) is indicated by benthic foraminiferal assemblages of the late Pliocene to Pleistocene.
\end{abstract}

\section{INTRODUCTION}

During Leg 57 of the Deep Sea Drilling Project four sites were drilled on the continental slope of the Japan Trench (Figure 1, Table 1) penetrating 4834 meters of sediments and recovering a total of 1521 meters of cores. Because of disconformities and intervals of severe dissolution of calcareous and siliceous faunas, these cores contain a discontinuous Late Cretaceous to late Pleistocene faunal record. Nevertheless, integrated studies of both calcareous and siliceous plankton provide reliable age determinations for Leg 57 sites (see biostratigraphic synthesis).

A total of 574 samples have been examined for benthic foraminifers from the four sites drilled on Leg 57 . Site 441, on the lower slope of the Japan Trench at 5655 meters below sea level, is barren of foraminifers. Site 438 and 440 , on the inner trench slope and midslope terrace, respectively, provide an upper Miocene to Pleistocene benthic foraminiferal record of varying abundance and preservation. Benthic foraminifers are relatively abundant in upper Pleistocene and upper Pliocene sediments but are rare in lower Pleistocene to uppermost Pliocene (0.9-2.0 m.y.) and lower Pliocene sediments owing to dissolution during these periods. Benthic foraminifers recovered from Miocene sediments are generally low in abundance and poorly preserved. Inner trench slope Site 439 yielded upper Miocene, lower Miocene, upper Oligocene, and Upper Cretaceous benthic assemblages; preservation and abundance at this site are generally poor.

\section{METHODS}

Samples of approximately 20 cubic $\mathrm{cm}$ were washed through a 250 -mesh screen $(0.62 \mu \mathrm{m})$ and dried. Unconsolidated sediments were soaked in water, and, when necessary, disaggregation was aided by the addition of small amounts of hydrogen peroxide. Hydrogen peroxide was routinely added to more consolidated sediments. The hard, black, fissile shale (Cretaceous) encountered at the bottom of Hole 439 was disaggregated by adding Quaternary 0 to the solution and boiling for several hours. Because frequencies of benthic foraminifers were generally low, useful quantitative analysis was possible for only Site 438 . Qualitative analysis of species abundance was made for Sites 439 and 440 with the following notation regarding abundance: abundant (A), more than 30 specimens; common (C), between 15 and 30 specimens; few ( $F$ ), is between 5 and 15 specimens; rare $(R)$, fewer than 5 specimens; for preservation, $G$ is good; M, moderate; P, poor. Labeling of samples follows the DSDP convention: hole-core-section (interval in $\mathrm{cm}$ ).

\section{BIOSTRATIGRAPHY}

Benthic foraminiferal assemblages of the Japan Trench sites contain faunal elements common to both the Pacific coast of Japan and to the northwest coast of 

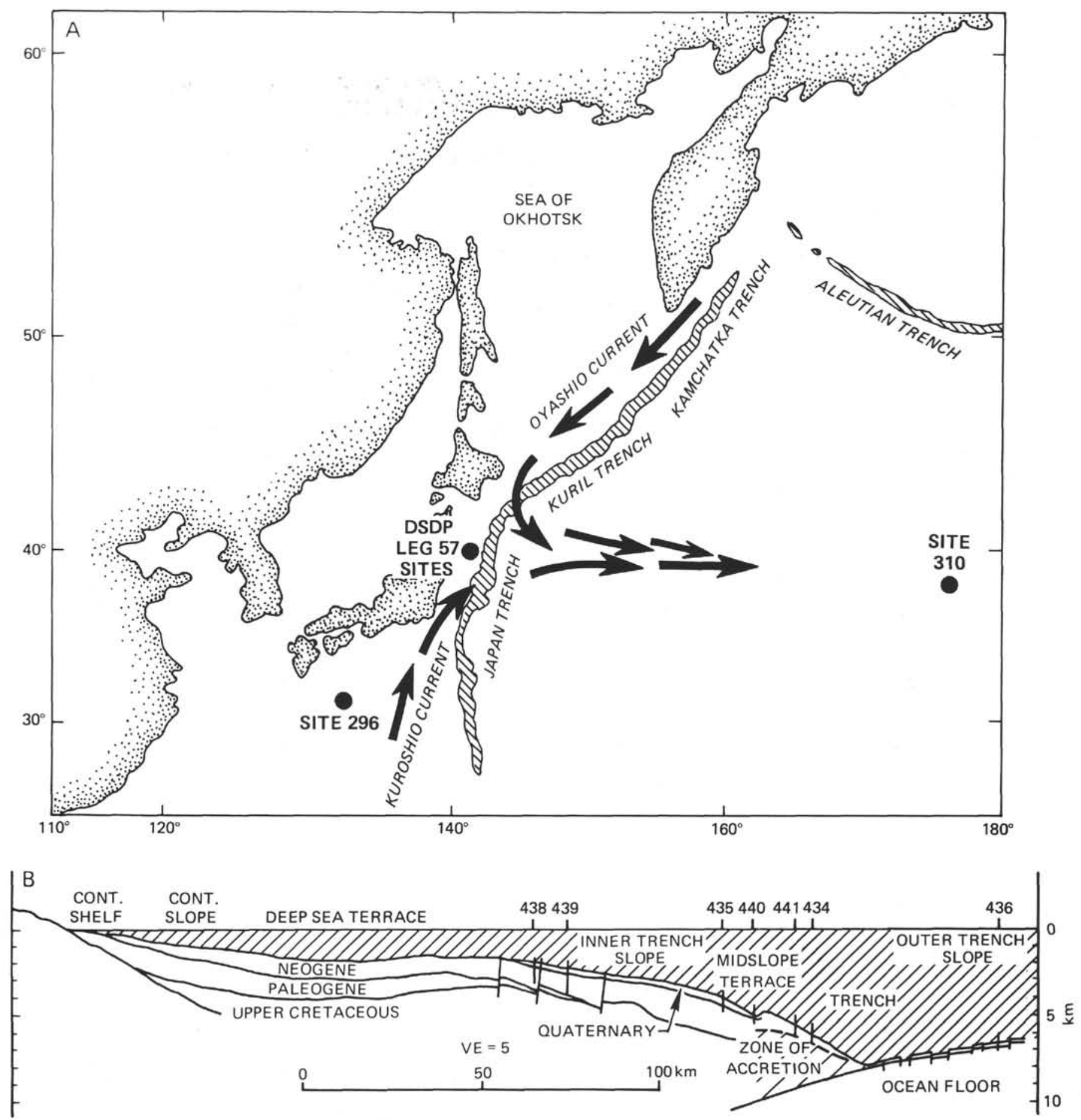

Figure 1. A. Location of DSDP Leg 57 sites and major current circulation. B. Schematic cross sections showing drill site locations for DSDP Legs 56 and 57.

America as well as species characteristic of the coastal regions of Japan. For example, the Pleistocene and Pliocene benthic faunas recovered from Sites 438 and 440 are similar to those from the Pacific coastal region of Japan described by Matoba $(1967,1976)$, Ujiie et al. (1977), Saidova (1961), Ishiwada (1964), and also similar to faunas described from the marginal northeast $\mathrm{Pa}$ cific by Uchio (1960), Bandy (1953), Ingle (1973), Loe- blich and Tappan (1953), Cushman and Gray (1946), Martin (1952), and others. Many of these species, from the Island of Car Nicobar, were originally described by Schwager (1867).

Miocene to Oligocene faunal assemblages of the Japan Trench sites are also similar to those from the northeast Pacific coast described by White (1956), Pierce (1956), Kleinpell (1938), Mallory (1959), and Sullivan 
TABLE 1

Leg 57 Site Data

\begin{tabular}{lcccrrr}
\hline Hole & Latitude & Longitude & $\begin{array}{c}\text { Sub-bottom } \\
\text { Depth } \\
(\mathrm{m})\end{array}$ & $\begin{array}{c}\text { Penetration } \\
(\mathrm{m})\end{array}$ & $\begin{array}{c}\text { Total Core } \\
\text { Recovered } \\
(\mathrm{m})\end{array}$ & $\begin{array}{c}\text { Oldest Sediment } \\
\text { Cored }\end{array}$ \\
\hline 438 & $40^{\circ} 37.75^{\prime} \mathrm{N}$ & $143^{\circ} 13.90^{\prime} \mathrm{E}$ & 1552 & 109.5 & 81.9 & L. Pliocene \\
$438 \mathrm{~A}$ & $40^{\circ} 37.79^{\prime} \mathrm{N}$ & $143^{\circ} 14.15^{\prime} \mathrm{E}$ & 1558 & 878.0 & 555.3 & M. Miocene \\
$438 \mathrm{~B}$ & $40^{\circ} 37.80^{\prime} \mathrm{N}$ & $143^{\circ} 14.80^{\prime} \mathrm{E}$ & 1564 & 1040.7 & 192.6 & L. Miocene \\
439 & $40^{\circ} 37.61^{\prime} \mathrm{N}$ & $143^{\circ} 18.63^{\prime} \mathrm{E}$ & 1656 & 1157.5 & 163.0 & U. Cretaceous \\
440 & $39^{\circ} 44.13^{\prime} \mathrm{N}$ & $143^{\circ} 55.74^{\prime} \mathrm{E}$ & 4509 & 73.0 & 50.4 & Pleistocene \\
$440 \mathrm{~A}$ & $39^{\circ} 44.13^{\prime} \mathrm{N}$ & $143^{\circ} 55.74^{\prime} \mathrm{E}$ & 4509 & 139.5 & 33.5 & Pleistocene \\
$440 \mathrm{~B}$ & $39^{\circ} 44.13^{\prime} \mathrm{N}$ & $143^{\circ} 55.74^{\prime} \mathrm{E}$ & 4509 & 814.0 & 401.9 & U. Miocene \\
441 & $39^{\circ} 45.05^{\prime} \mathrm{N}$ & $144^{\circ} 04.55^{\prime} \mathrm{E}$ & 5655 & 293.0 & 16.6 & L. Pliocene \\
$441 \mathrm{~A}$ & $39^{\circ} 45.05^{\prime} \mathrm{N}$ & $143^{\circ} 04.59^{\prime} \mathrm{E}$ & 5644 & 662.0 & 19.7 & U. Miocene \\
$441 \mathrm{~B}$ & $39^{\circ} 45.08^{\prime} \mathrm{N}$ & $144^{\circ} 04.60^{\prime} \mathrm{E}$ & 5635 & 687.0 & 5.5 & U. Miocene \\
\hline
\end{tabular}

(1962); to those from the Central Pacific described by Douglas (1973); and to those from the Japan region described by Asano (1953a, 1953b, 1958). A large number of late Miocene to Pliocene species of the Japan Trench sites appear to be cosmopolitan and have recently been discussed, with respect to paleobathymetry from the Mediterranean El Cuervo section of Andalusia, Spain, by Berggren et al. (1976).

The Upper Cretaceous fauna present at Site 439 contains species from Hokkaido described by Takayanagi (1960) as well as from the Rosario Formation of Southern California described by Sliter (1968).

In the following discussion on late Tertiary benthic foraminiferal assemblages, radiometric dates are based on plankton datum levels and correlations; $\mathrm{F}=$ foraminifera (Keller, this volume), D = diatom (Barron, this volume), $\mathrm{R}=$ radiolaria (Reynolds, this volume), $\mathrm{N}=$ nannofossil (Shaffer, this volume). Important datum levels are indicated in the range charts of benthic species (Figures 2-5).

\section{Site 438}

Site 438 was drilled on the outer slope of the deep sea terrace $170 \mathrm{~km}$ seaward of Tohoku Island Arc at a depth of 1550 meters below sea level. Three holes, 438, 438A and $438 \mathrm{~B}$, were drilled at this site, reaching a sub-bottom depth of 110,878 , and 1040 meters, respectively, the oldest sediments date from the early Miocene.

\section{Hole 438}

The 110 meters of upper Pliocene to Pleistocene sediments penetrated in Hole 438 consist of sandy, silty clay with erratic pebbles. Benthic foraminifers are common to abundant in the upper Pleistocene sediments, absent because of dissolution in sediments spanning $0.9(\mathrm{D}, \mathrm{N})$ to 2.5 (F)m.y., and rare to few in upper Pliocene Cores 9 to 12 (Table 2). Throughout the upper Pliocene to Pleistocene sequence foraminiferal assemblages consist of more than 60 per cent benthic foraminifers, suggesting that dissolution occurred throughout this interval (Figure 2). According to diatom (Barron, this volume) and nannofossil (Shaffer, this volume) data, the Pliocene/Pleistocene boundary falls between Cores 3 and 4 .

The range and relative abundance of benthic foraminifers of Hole 438 are illustrated in Figure 2. Elphidium batialis, a deep-water species (Ishiwada, 1964; Saidova,
1961; Matoba, 1976), is the most abundant species in upper Pleistocene assemblages, together with Nonion labradorica, Epistominella pacifica, Bucella inusitata, Chilostomellina fimbriata, Cassidulina norcrossi, $C$. islandica, Uvigerina akitaensis, $U$. cf. yabei, and $U$. juncea. This group of species is characteristic of the late Pleistocene fauna observed in the Japan Trench sites and correlates well with the present water depth of 1500 meters at this site.

The late Pliocene benthic foraminiferal assemblage at Site 438 indicates that deposition occurred in somewhat deeper waters $(1500-2000 \mathrm{~m})$ during this time. This fauna is characterized by the following assemblage: Uvigerina juncea, $U$. proboscidae, Bulimina striata, Martinottiella communis, Melonis affinis, M. pompilioides, Bolivinita quadrilatera, Nodosaria longiscata, and $N$. vertebralis (Table 2). The rare shallow-water species present within Hole 438, Elphidium clavatum and Quinqueloculina sp., suggest that downslope displacement of sediments has been negligible.

\section{Hole 438A}

The 878 meters of sediments penetrated in Hole 438A span the early Miocene to Pleistocene. Benthic foraminifers occur in varying abundance throughout this sequence (Table 3 ), reflecting a dissolution pattern similar to that observed in Hole 438 for the late Pliocene to Pleistocene (Figures 2 and 3). Throughout the Miocene to lower Pliocene sediments, benthic foraminifers are rare to few and poorly preserved. Table 3 provides the quantitative data in terms of number of species and specimens counted for Hole 438A, and Figure 3 illustrates abundance and ranges of dominant species.

The late Pleistocene benthic foraminiferal assemblage of Hole 438A (Assemblage 1, Figure 3) is very similar to that in Hole 438 in both abundance and characteristic species, with the exception of Bulimina exilis, which occurs abundantly in Hole 438A but not in Hole 438. This faunal assemblage is characteristic of the present water depth in the area $(1500 \mathrm{~m})$. As in Hole 438, foraminiferal faunas are severely dissolved in the interval spanning $0.9(\mathrm{D}, \mathrm{N}) \mathrm{m} . \mathrm{y}$. to about 2.0 to $2.2(\mathrm{~F})$ m.y. (Cores 438A-2,CC to 438A-4-5).

The latest Pliocene interval (Cores 438A-4, CC-438A5-5 [15]), spanning from about 2.0 to 2.2 ([F] m.y. to 2.4 [D] m.y.) has a faunal assemblage (Assemblage 2, 
TABLE 2

Distribution of Benthic Foraminifers in Hole 438

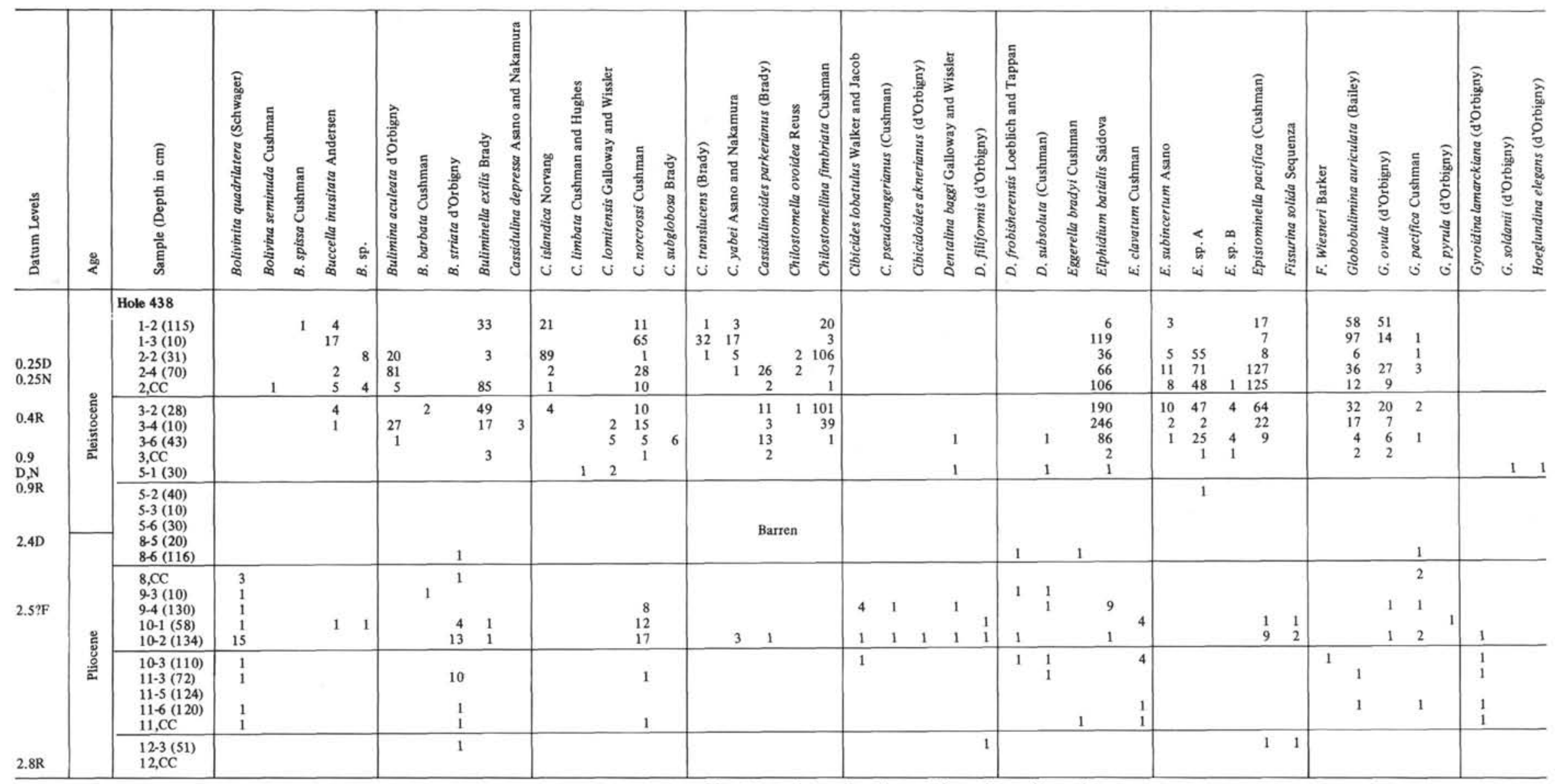

Note: $\mathrm{D}=$ diatom (Barron, this volume), $\mathrm{N}=$ nannofossil (Shaffer, this volume), $\mathrm{F}=$ benthic foraminifera (Keller, this volume). Preservation: $\mathrm{P}=$ poor, $\mathrm{M}=$ moderate, $\mathrm{G}=$ good. 
TABLE 2 - Continued

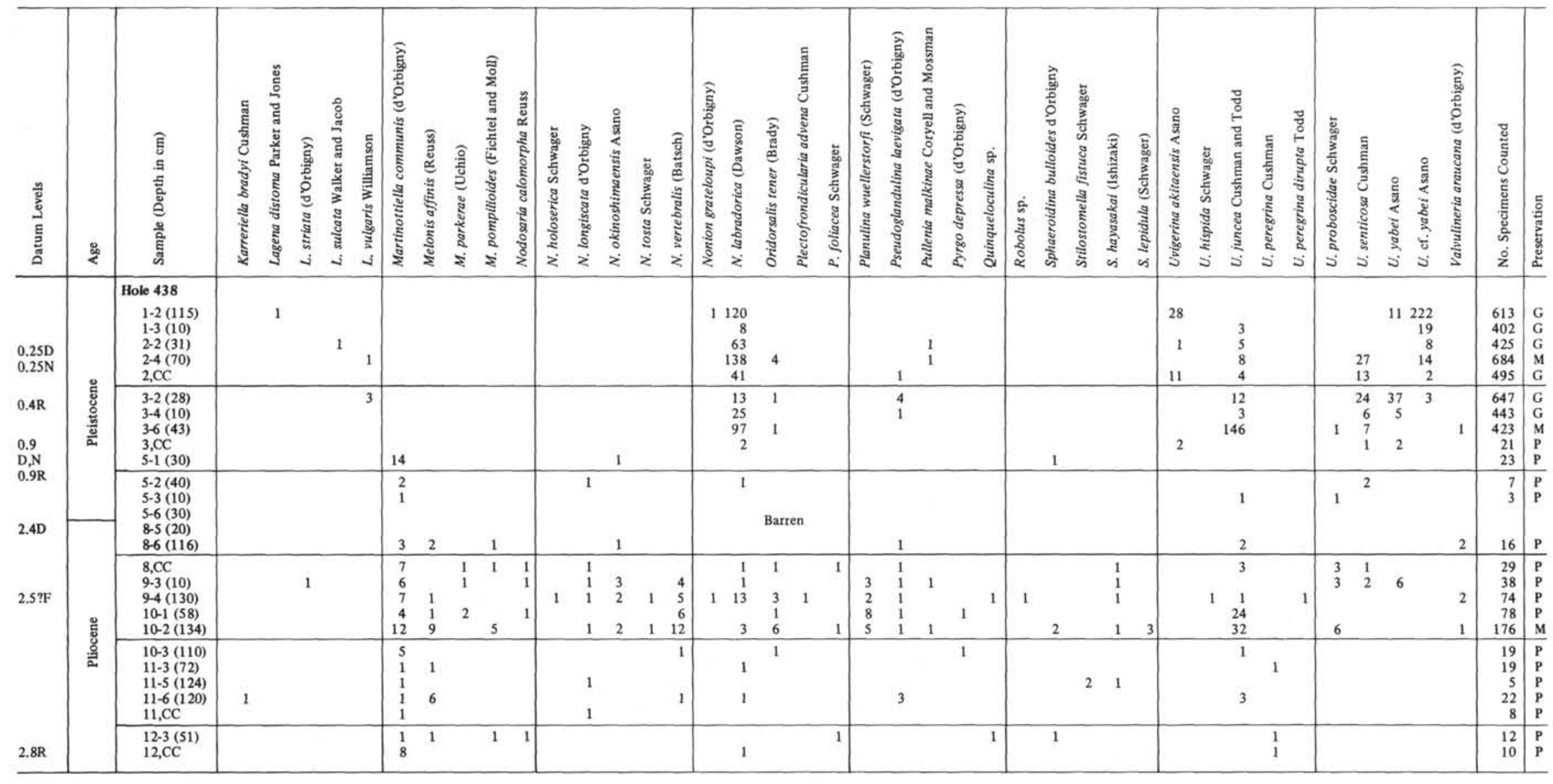




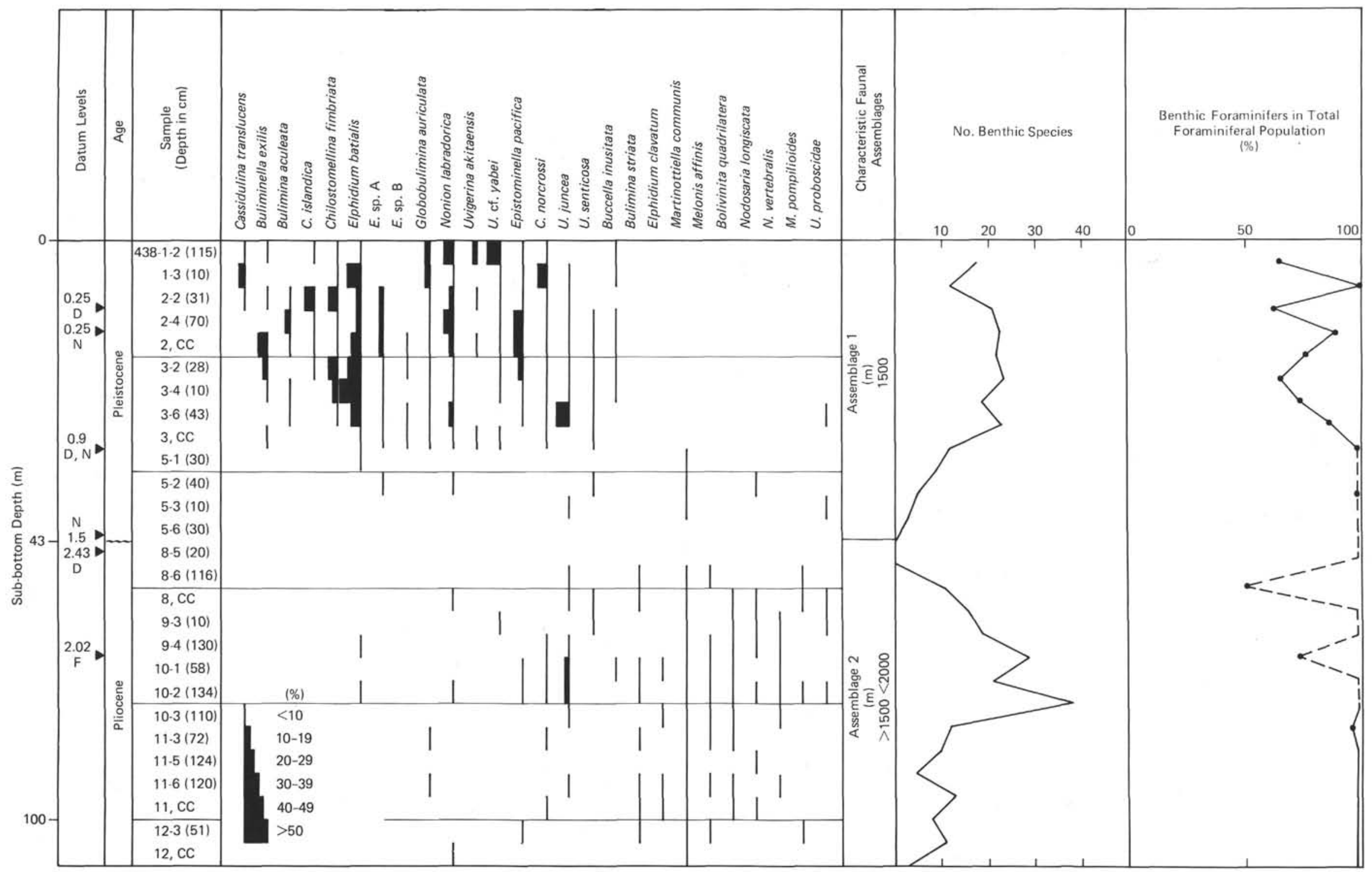

Figure 2. Range and relative abundance of dominant species, total number of benthic species, and percentage of benthic foraminifers in total foraminiferal fauna in Hole 438. ( $D=$ diatom [Barron, this volume], $N=$ nannofossil [Shaffer, this volume], $R=$ radiolaria [Reynolds, this volume], $F=$ planktonic foraminifera [Keller, this volume].) 
Figure 3) similar to that within the same time interval in Hole 438 (Figures 2 and 3). The following species are dominant within this assemblage: Cassidulina norcrossi, C. yabei, Bolivinita quadrilatera, Bulimina striata, Nodosaria longiscata, Stilostomella fistucca, and Uvigerina subperegrina. These species suggest that deposition occurred between 1500 and 2000 meters sub-bottom. Up to 10 per cent Elphidium clavatum, a shallow-water species in recent faunal assemblages, is present in two samples: 438A-5-3(61), with 58 specimens, and 438A-5-4 (18), with 25 specimens (Table 3 ). This suggests that either (1) there was considerable downslope movement of sediments (i.e., slump, debris flow) at this interval or (2) that this species inhabited deeper waters during the late Pliocene than at present. Absence of significant numbers of shallow-water species within this interval favors the second interpretation.

A characteristic late Pliocene assemblage (Assemblage 3, Figure 3) can be recognized between Cores $6, \mathrm{CC}$ and $12, \mathrm{CC}$, which may correspond to the lower part of Hole 438. Dominant species within this interval are Cassidulina norcrossi, Bulimina striata, Buccella inusitata, Stilostomella lepidula, Martinottiella communis, Nodosaria vertebralis, and Nonion labradorica. This assemblage suggests deposition at a water depth of about 2000 meters. Rare specimens of shallow-water species, Bolivina decussata, Cibicides lobatulus, $C$. aknerianus, Elphidium clavatum (?), Rosalina bradyi, and Trifarina fluens, indicate that displacement of species by downslope movement has been minimal.

A fourth assemblage can be recognized spanning the lower Pliocene interval. The dominant species within this interval are Uvigerina senticosa, U. proboscidae, Nonion labradorica, Melonis affinis, Martinottiella communis, Buccella inusitata, Nodosaria longiscata, and Bulimina striata. Abundance of $U$. senticosa and $U$. proboscidae suggests that deposition occurred below 2000 meters. Rare occurrences of Quinqueloculina sp. Bolivina marginata, Cibicides lobatulus, and C. aknerianus also suggest that downslope displacement of species has been minimal during the lower Pliocene.

\section{Hole 438B}

Hole 438B contains only rare benthic foraminifers such as Martinottiella communis, Nodosaria longiscata, Nonion nicobarensis, Pullenia quinqueloba, Sphaeroidina bulloides, and Uvigerina cf. hootsi. Diatom faunas indicate a lower Miocene age for Hole 438B Cores 5,CC to $23, \mathrm{CC}$ (Barron, this volume).

\section{Site 439}

Site 439 was drilled $5 \mathrm{~km}$ east of Site 438 at a depth of 1656 meters below sea level. The primary objective of Site 439 was to penetrate the acoustic basement, an objective which failed at Site 438. Because the late Neogene biostratigraphic and sedimentary record was obtained at Site 438 , Site 439 was interval cored to the early Miocene and the remaining section continuously cored through the acoustic basement. Four spot cores taken through the upper and middle Miocene and the continuously cored early Miocene section provide age and bio- stratigraphic correlation of Site 439 with Site 438 (see biostratigraphic synthesis). The two sites provide a unique, albeit discontinuous, Upper Cretaceous to Pleistocene faunal record which largely corroborates the geologic history of this area as interpreted from onland sections of Japan and particularly the northeastern part of Honshu Island.

Benthic foraminifers at Site 439 are generally rare to few and poorly preserved except for horizons in lower Miocene and upper Oligocene sediments, where relatively diverse faunal assemblages are preserved. Figure 4 illustrates the ranges and relative abundance of species at Site 439. Although most species present are not age-diagnostic, they clearly exhibit faunal breaks indicative of environmental changes. Miocene age calls are based on diatom (Barron, this volume), radiolarian (Reynolds, this volume), and nannofossil (Shaffer, this volume) biostratigraphy. Planktonic foraminifers are rare in upper Miocene Core 439-1, and only two specimens of Catapsydrax unicavus were present in lower Miocene Cores 14 and 15.

\section{Miocene}

The benthic foraminiferal assemblage present in Core 439-1 is similar to the late Miocene to Pliocene assemblage recovered from Site 438A (Figure 3). This assemblage is dominated by Uvigerina proboscida, Martinottiella communis, and Nodosaria longiscata (Figure 4), suggesting that deposition occurred in lower middle bathyal $(1500-2000 \mathrm{~m})$ to bathyal $(2000 \mathrm{~m}+)$ environment. Cores 2 to 11 are barren of foraminifers. Cores 13 to 15 contain a diverse benthic assemblage consisting of the following species characteristic of the early Miocene: Uvigerina gallowayi, $U$. cf. hootsi, Uvigerinella californica, Epistominella cf. relizensis, Gyroidina iojimaensis, and Buccella sp. The faunal break between this assemblage and the late Miocene assemblage in Core 1 supports a hiatus observed in the diatom stratigraphy between Cores 11 and 12 (Barron, this volume).

\section{Upper Oligocene}

Another distinct benthic faunal assemblage occurs in Cores 22 to 25 , following a barren interval encompassed by Sections 439-17-4 to 439-20, CC (Figure 4). This assemblage appears to date from the upper Oligocene and contains many species described by Asano (1958) from Oligocene sediments of Hokkaido; these sediments are now considered to date from the early Miocene age. The most commonly occurring species are Elphidium mabuttii, Cribroelphidium sp., Epistominella danvillensis, Cassidulina laevigata, Bolivina substriatula, Gyroidina iojimaensis, Cyclammina incisa, C. pacifica, and Buccella sp. (Figure 4). Because Cores 26 to 37 contain very rare and badly damaged specimens, no age determination has been possible. However, the conglomerate underlying this unit yielded an argon date of $21.2 \pm 0.7$ m.y. (Yanagisawa et al., this volume) and a potassiumargon date of $23.4 \pm 5.5$ m.y. (Moore and Dalrymple, this volume), suggesting that this fauna dates indeed from latest Oligocene to earliest Miocene. 
TABLE 3

Distribution of Benthic Foraminifers in Holes 438A and 438B

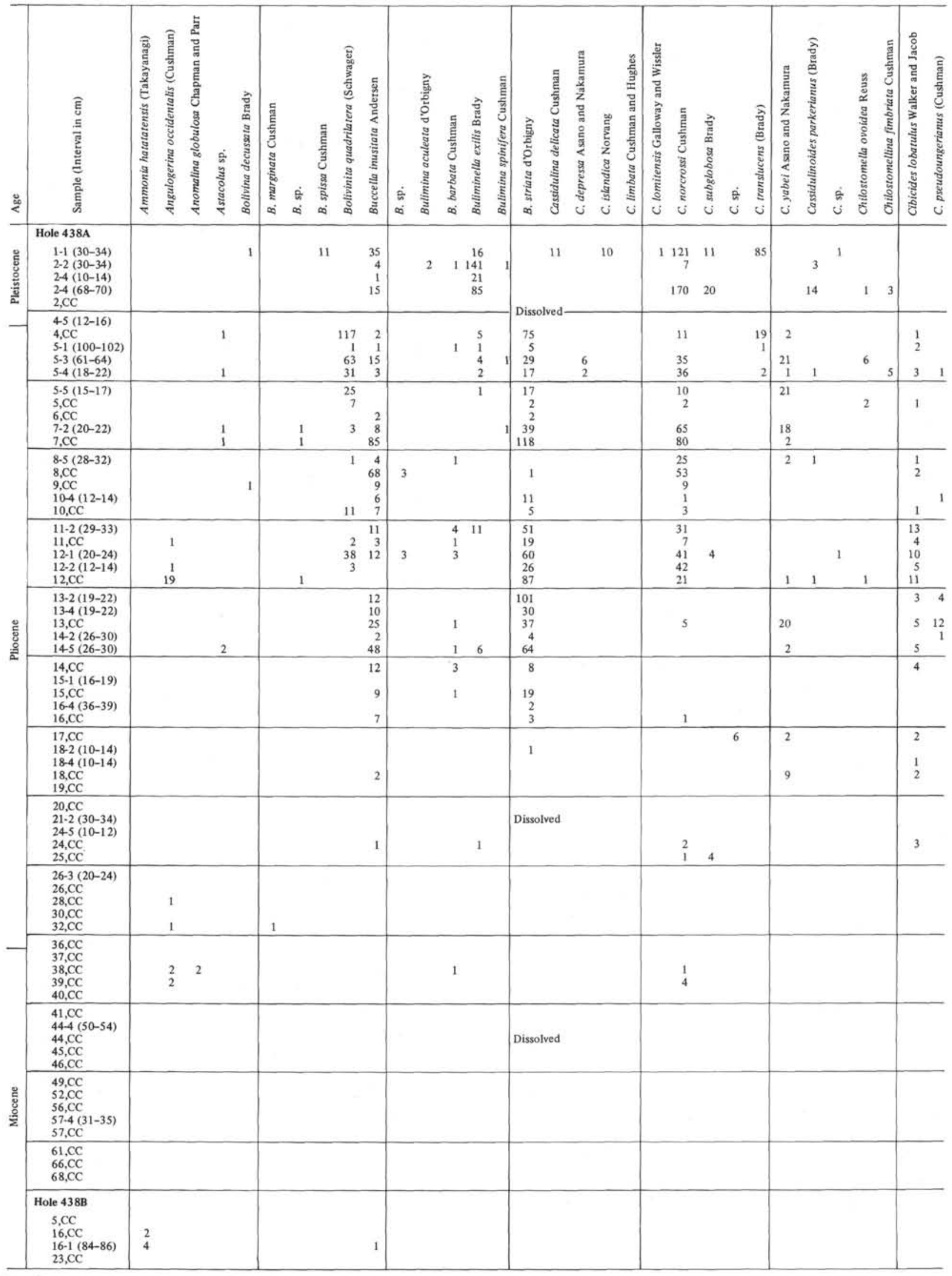

Note: Preservation: $\mathrm{P}=$ poor, $\mathrm{M}=$ moderate, $\mathrm{G}=$ good. 
TABLE 3 - Continued

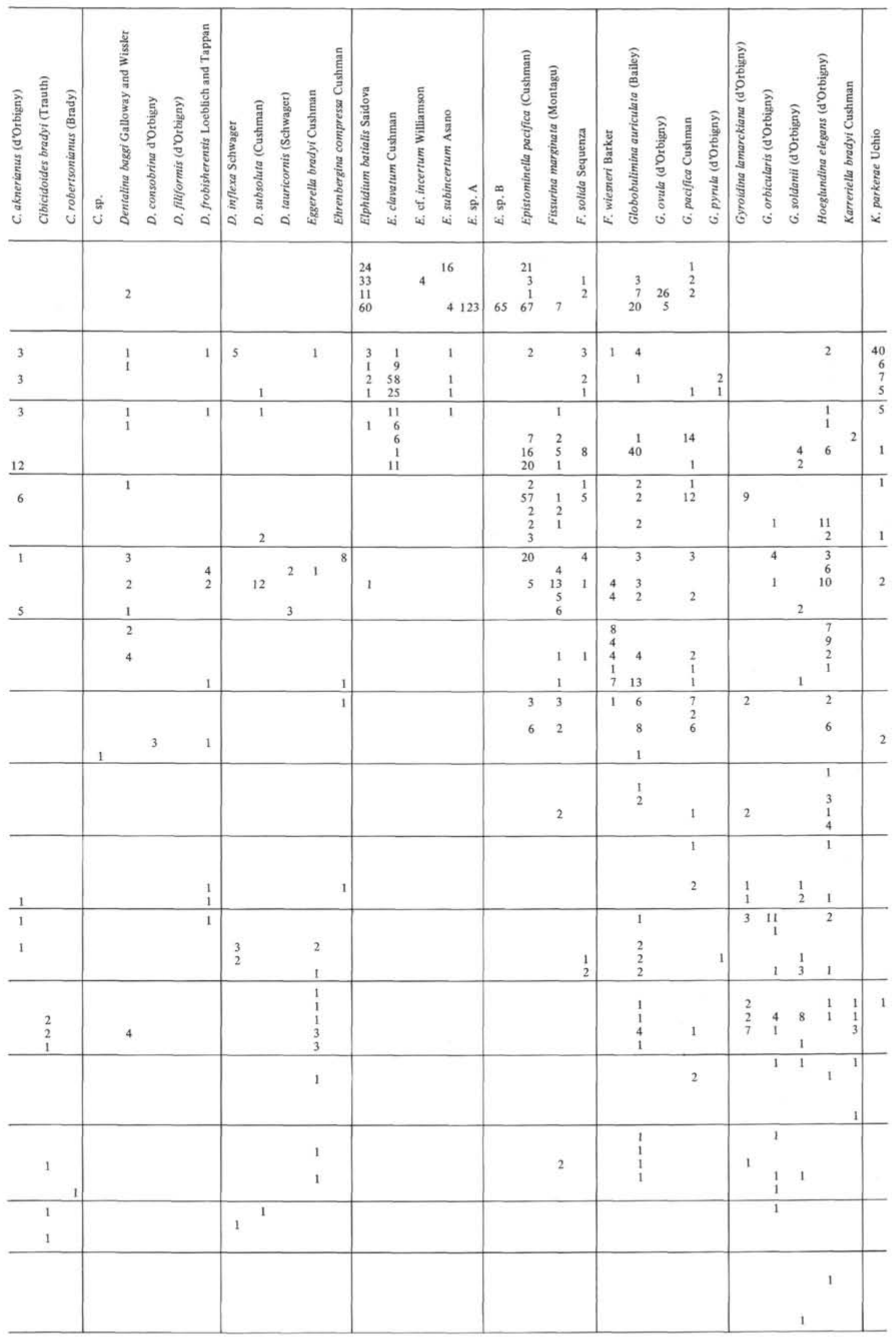


G. KELLER

TABLE 3 - Continued

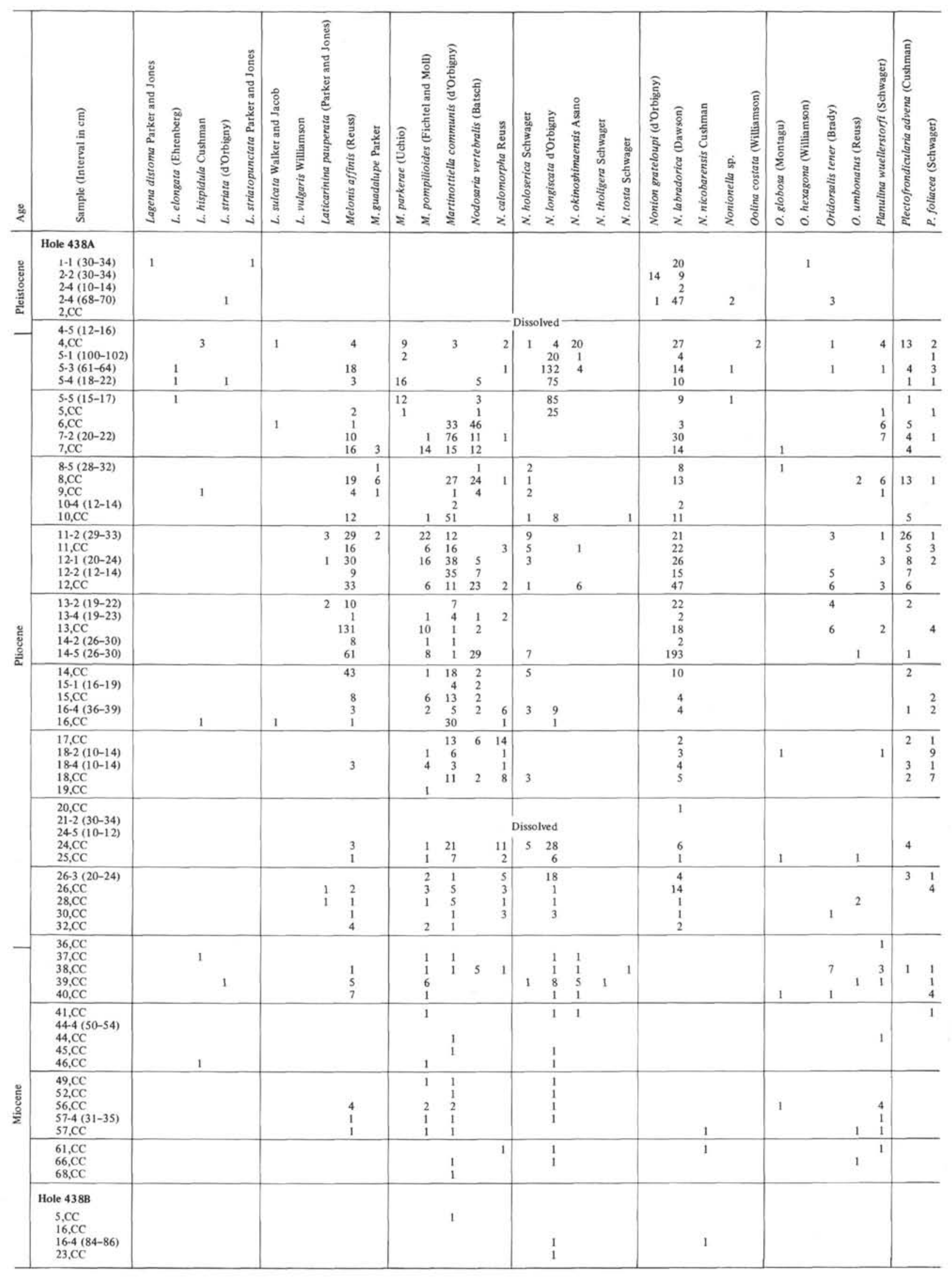

844 
TABLE 3 - Continued

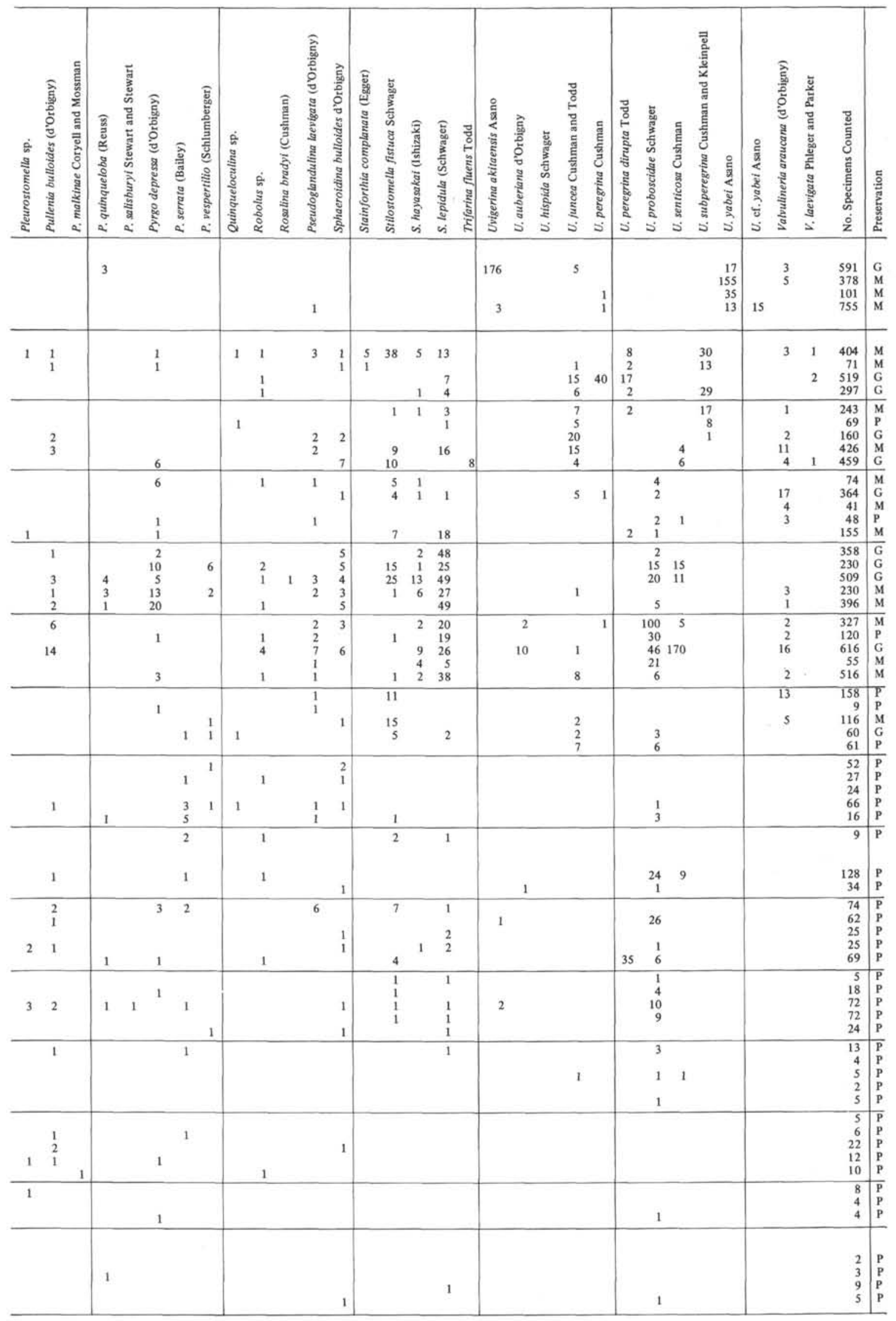




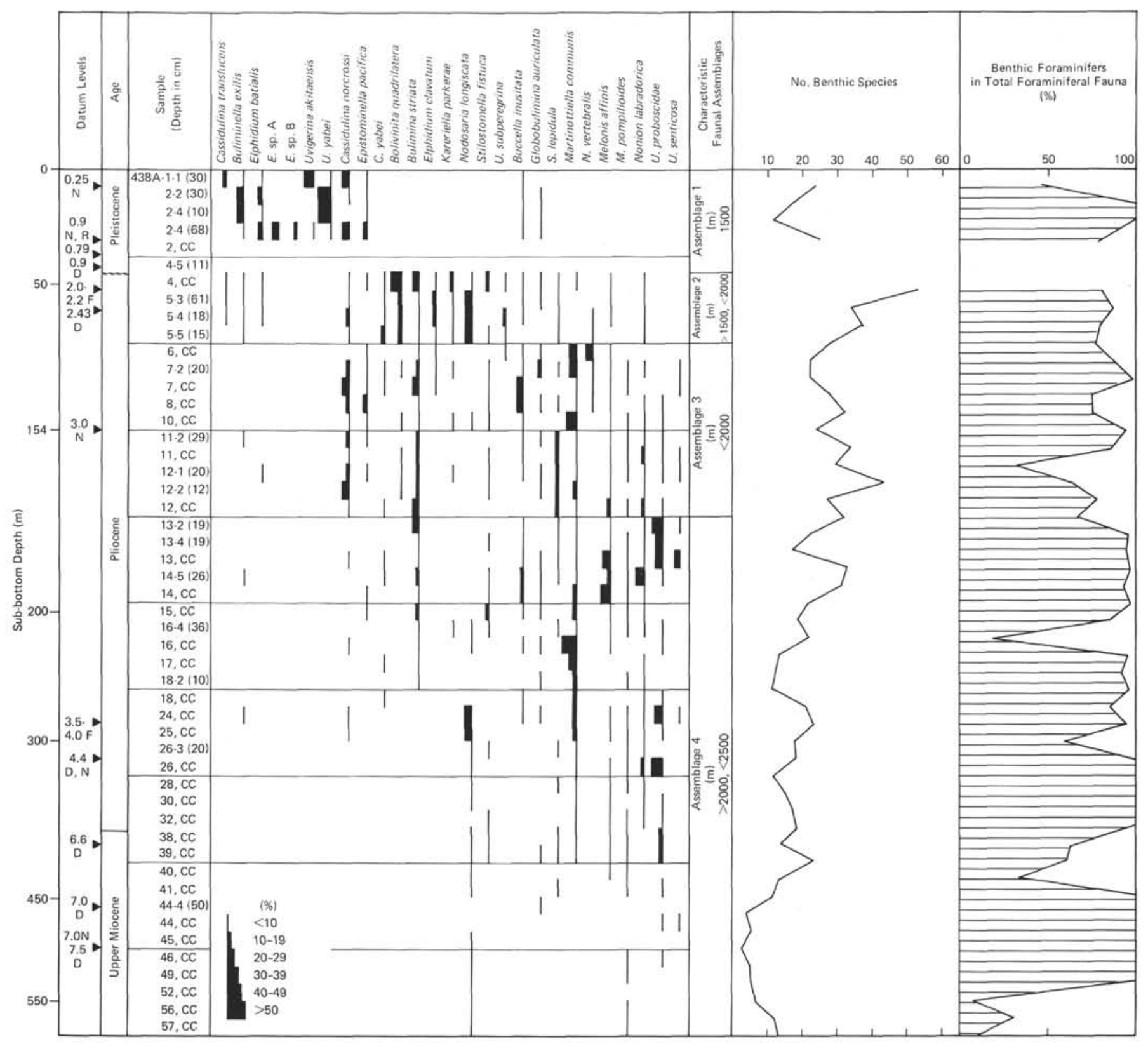

Figure 3. Range and relative abundance of dominant species, total number of benthic species, and percentage of benthic foraminifers in total foraminiferal fauna in Hole 438A. ( $D=$ diatom [Barron, this volume], $N=$ nannofossil [Shaffer, this volume], $R=$ radiolaria [Reynolds, this volume], $F=$ planktonic foraminifera [Keller, this volume].)

\section{Upper Cretaceous}

Sediments in Sections 439-37-2 to 439-39, CC consist of well-indurated silicified claystone interbedded with thin calcareous silt beds. This lithologic unit is separated from the overlying massive sandstone of upper Oligocene age by 48 meters of mud-supported conglomerate.

Examination of large samples $(100 \mathrm{cc})$ of the silicified claystone produced an arenaceous fauna of probable Upper Cretaceous age. Five genera have been identified: Haplophragmoides, Ammobaculites, Ammodiscus (Spirilina), Bathysiphon, and Lenticulina (Figure 4). Poor preservation permitted only the following three species to be identified positively: Ammodiscus (Spirilina) hashi- motoi Takayanagi, Ammodiscus (Spirilina) cretacea (Reuss), and Haplophragmoides cf. formosus Takayanagi.

Some 80 specimens were found in two samples, 439 $38-1(20-30 \mathrm{~cm})$ and $439-39-1(10-50 \mathrm{~cm})$; among these Ammodiscus cretacea is most commonly present. Ammodiscus hashimotoi, A. cretacea, and Haplophragmoides cf. formosus have been observed by Takayanagi (1960) from the Upper Cretaceous of Hokkaido (middle to upper Yezo Group = Cenomanian to Campanian). Haplophragmoides cf. formosus has not been observed in sediments younger than Upper Cretaceous (Sliter, 1978). All three species and the above-mentioned genera have also been observed by Sliter (1968) in the Rosario Formation (Upper Cretaceous) of southern California. 


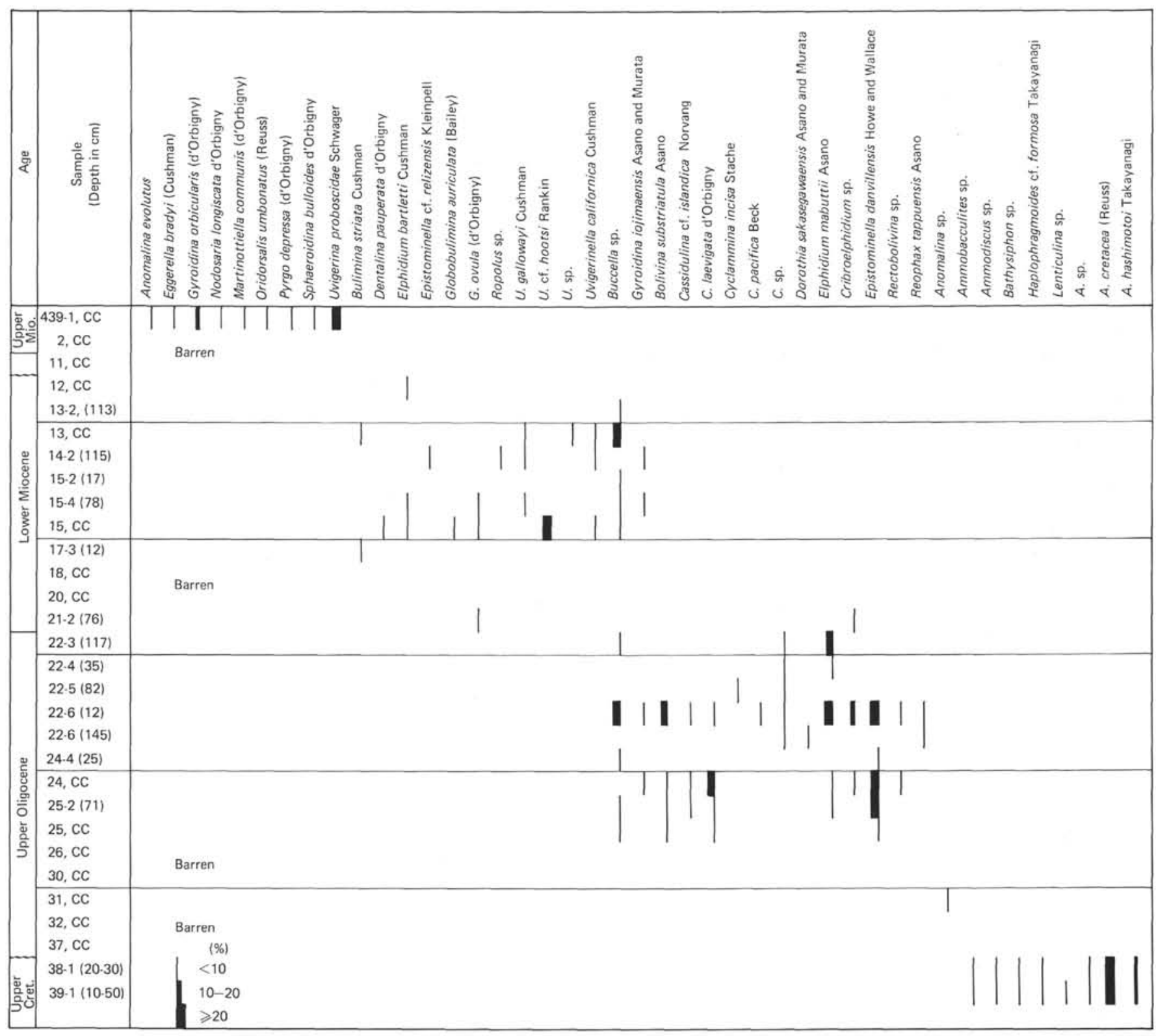

Figure 4. Range, distribution, and relative abundance of benthic foraminifers in Hole 439.

\section{Site $\mathbf{4 4 0}$}

Site 440 is located on the midslope terrace at a water depth of 4509 meters (Figure 1). More than 800 meters of sediments were cored in three holes, representing uniform hemipelagic siliceous mudstones similar in composition to sediments at Sites $\mathbf{4 3 8}$ and $\mathbf{4 3 9}$ farther upslope. These sediments represent relatively discontinuous late Miocene to Pleistocene benthic faunas similar to those at Site 438 . Table 4 provides a qualitative abundance chart for benthic foraminifers recovered from Site 440 . Ranges and relative abundance of important species are presented in Figure 5.

Site 440 contains a more expanded upper Pleistocene sequence than that recovered at Site 438. Though similar to those at Site 438, they also include a number of deeper-water species reflecting the deeper-water loca- tion of Site 440. The following species are dominant: Buliminella exilis, Cassidulina depressa, C. norcrossi, Elphidium batialis, Elphidium sp. A, Elphidium sp. B, Globobulimina auriculata, Nonion labradorica, Nonionella sp., Melonis pompilioides, and Uvigerina sentico$s a$. There are a number of shallow-water species, indicating that downslope transport occurred throughout this late Pleistocene sequence: Ehrenbergina compressa, Pullenia sphaeroides, Sigmoilina sp., Bolivina decussata, B. seminuda, Cassidulina islandica, C. yabei, Cassidulinoides parkerianus, Cibicidoides aknerianus, Elphidium subincertum, Gyroidina orbicularis, and Quinqueloculina sp. (Table 4). Of the shallow-water species, Ehrenbergina compressa is most common and reaches 10 per cent in Sample 440-8,CC (Figure 5).

Because dissolution of foraminifers is severe throughout the Pliocene to the early Pleistocene, there is low 
TABLE 4

Distribution and Relative Abundance of Benthic Foraminifers in Holes 440, 440A, and 440B

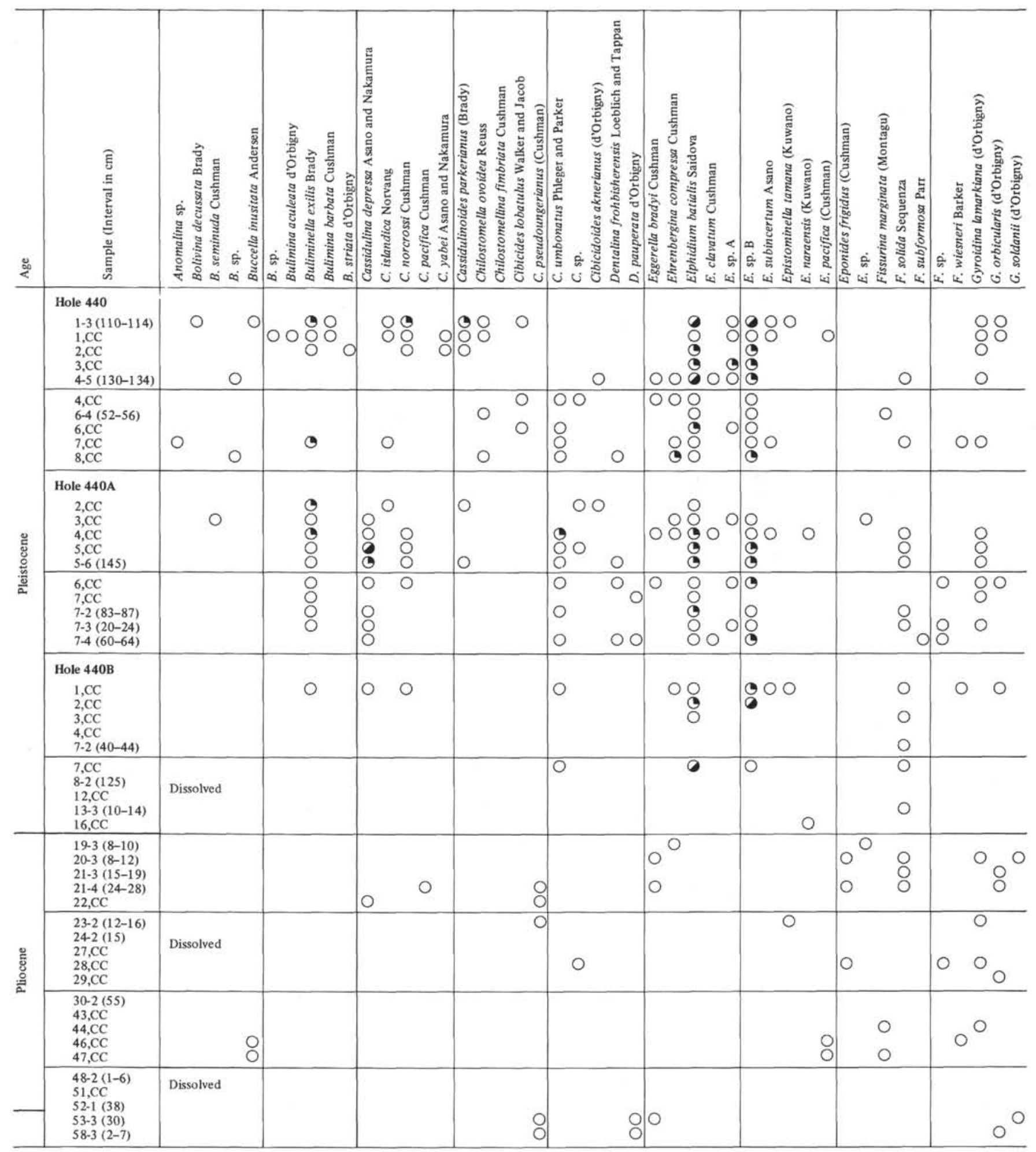

Note: Number of specimens: $O=5, O=5-15, Q=15-30$. Abundance: $R=$ rare $(<10), F=$ few $(10-50), C=$ common $(50-150), A=a b u n d a n t(>150)$. Preservation: $P=$ poor, $\mathrm{M}=$ moderate, $\mathrm{G}=$ good. Intervals of dissolution are marked "Dissolved" and contain very rare specimens. 
TABLE 4 - Continued

\begin{tabular}{|c|c|c|c|c|c|c|c|c|c|c|}
\hline 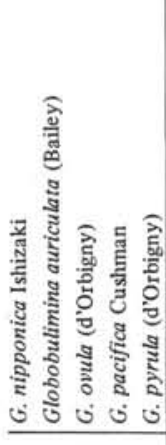 & 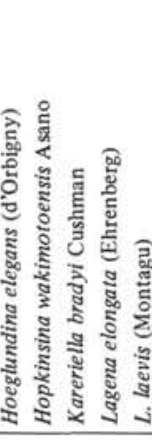 & 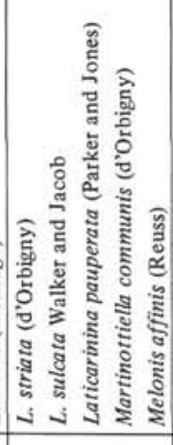 & 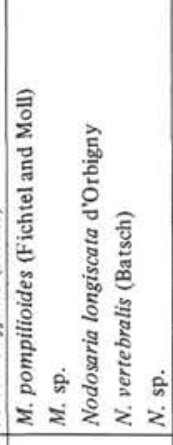 & 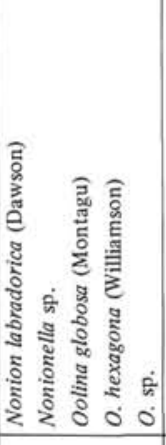 & 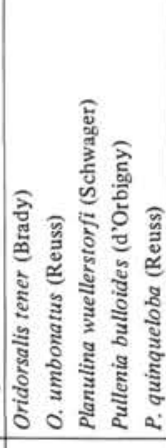 & 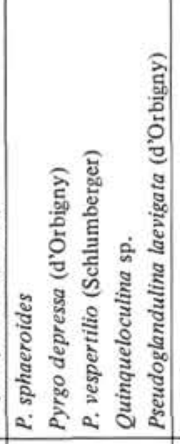 & 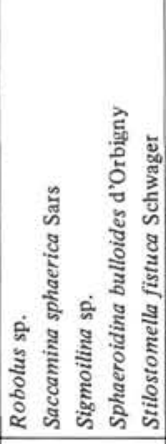 & 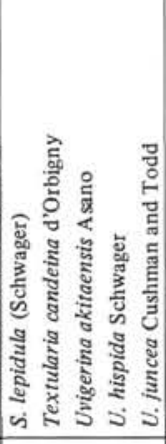 & 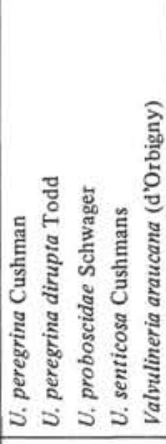 & 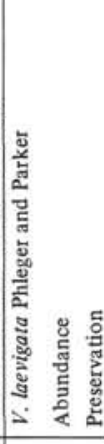 \\
\hline $\begin{array}{l}800 \\
8000 \\
\circ 0\end{array}$ & & & 0 & $\overbrace{0}^{9} 00$ & $\begin{array}{l}00 \\
00 \\
\end{array}$ & $\begin{array}{ll}0 \\
0 \\
0\end{array}$ & 0 & 00 & 09 & $\begin{array}{lll} & \mathrm{A} & \mathrm{G} \\
\mathrm{O} & \mathrm{A} & \mathrm{G} \\
\mathrm{F} & \mathrm{P} \\
\mathrm{F} & \mathrm{P} \\
\mathrm{F} & \mathrm{M}\end{array}$ \\
\hline ○ & & & O & $0_{0}^{0}$ & 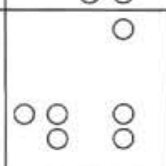 & $80^{\circ}$ & $\begin{array}{ll}0 & \\
0 & \\
0 & \\
& 0\end{array}$ & 8 & $0^{0} 0$ & $\begin{array}{ll}\mathrm{F} & \mathrm{P} \\
\mathrm{R} & \mathrm{P} \\
\mathrm{R} & \mathrm{P} \\
\mathrm{C} & \mathrm{M} \\
\mathrm{C} & \mathrm{P}\end{array}$ \\
\hline \multirow{3}{*}{0} & ० 8 & $\begin{array}{l}0_{0}^{\circ} \\
\mathrm{o}^{\circ}\end{array}$ & 0 & $0_{0}^{0} 0_{0}^{0}$ & $0^{0}$ & 00 & 0 & O & $\begin{array}{r}0 \\
0 \\
0 \\
0 \\
0\end{array}$ & $\begin{array}{ll}\mathrm{R} & \mathrm{P} \\
\mathrm{R} & \mathrm{P} \\
\mathrm{C} & \mathrm{G} \\
\mathrm{C} & \mathrm{M} \\
\mathrm{C} & \mathrm{M}\end{array}$ \\
\hline & & & 00 & 00 & $\begin{array}{lll}0 & 0 & 0 \\
0 & & \\
0 & & \end{array}$ & 0 & & $\begin{array}{ll}0 & 0 \\
& 0\end{array}$ & \begin{tabular}{|r|}
09 \\
0 \\
0 \\
$0 \quad 0$ \\
0
\end{tabular} & $\begin{array}{ll}\mathrm{C} & \mathrm{M} \\
\mathrm{F} & \mathrm{M} \\
\mathrm{F} & \mathrm{P} \\
\mathrm{F} & \mathrm{P} \\
\mathrm{R} & \mathrm{P}\end{array}$ \\
\hline & & $\begin{array}{rr}0 & 0 \\
& 0\end{array}$ & $\begin{array}{l}0 \\
0 \\
0\end{array}$ & 0 & $\begin{array}{lll}0 & 0 & 0\end{array}$ & $\begin{array}{l}000 \\
00\end{array}$ & $0^{0}$ & & $\begin{array}{l}0 \\
0 \\
0\end{array}$ & $\begin{array}{ll}\mathrm{C} & \mathrm{M} \\
\mathrm{R} & \mathrm{P} \\
\mathrm{R} & \mathrm{P} \\
\mathrm{R} & \mathrm{P} \\
\mathrm{R} & \mathrm{P} \\
\end{array}$ \\
\hline $\begin{array}{l}\text { Dissolved } \\
0\end{array}$ & 0 & & 00 & 0 & 0 & 0 & $0 \quad 8$ & 0 & Og & $\begin{array}{ll}\mathrm{F} & \mathrm{P} \\
& \\
\mathrm{F} & \mathrm{P} \\
\mathrm{R} & \mathrm{P} \\
\end{array}$ \\
\hline 응 & & & 800 & & $\begin{array}{l}0 \\
000\end{array}$ & $0_{0}^{0} 0_{0}^{0} 0$ & 0 & $\begin{array}{l}0 \\
8\end{array}$ & ${ }_{0}^{0}{ }^{0}$ & $\begin{array}{ll}\mathrm{R} & \mathrm{P} \\
\mathrm{R} & \mathrm{P} \\
\mathrm{R} & \mathrm{P} \\
\mathrm{F} & \mathrm{P} \\
\mathrm{R} & \mathrm{P} \\
\mathrm{R} & \mathrm{P}\end{array}$ \\
\hline Dissolved & & $0^{\circ}$ & 0 & & 0 & 0 & & & $0^{0}$ & $\begin{array}{ll}\mathrm{R} & \mathrm{P} \\
& \\
\mathrm{R} & \mathrm{P} \\
\mathrm{R} & \mathrm{P}\end{array}$ \\
\hline $\begin{array}{l}\text { Dissolved } \\
\text { O }\end{array}$ & & $\mathrm{O}^{\circ}$ & 0 & & $0 \quad 0$ & & O & 0 & 0 & $\begin{array}{ll}R & P \\
R & P \\
R & P\end{array}$ \\
\hline $\begin{array}{l}\text { Dissolved } \\
0\end{array}$ & 0 & $\begin{array}{l}8 \\
0\end{array}$ & O & & 000 & $\begin{array}{l}0 \\
0\end{array}$ & & 0 & & $\begin{array}{ll}R & P \\
R & P\end{array}$ \\
\hline
\end{tabular}

abundance and low diversity of species. The following deep-water species are characteristically present during this interval: Melonis pompilioides, M. affinis, Uvigerina senticosa, $U$. proboscidae, $U$. hispida, Martinottiella communis, and Nodosaria longiscata. Rare occurrences of the relatively shallow-water species Ehrenbergina compressa, Cyroidina orbicularis, Quinqueloculina sp., and Sigmoilina sp. indicate that some downslope displacement of sediments occurred throughout this sequence.

\section{PALEOBATHYMETRY}

Paleobathymetric interpretations of benthic foraminifers are made from known depth ranges of living spe- 


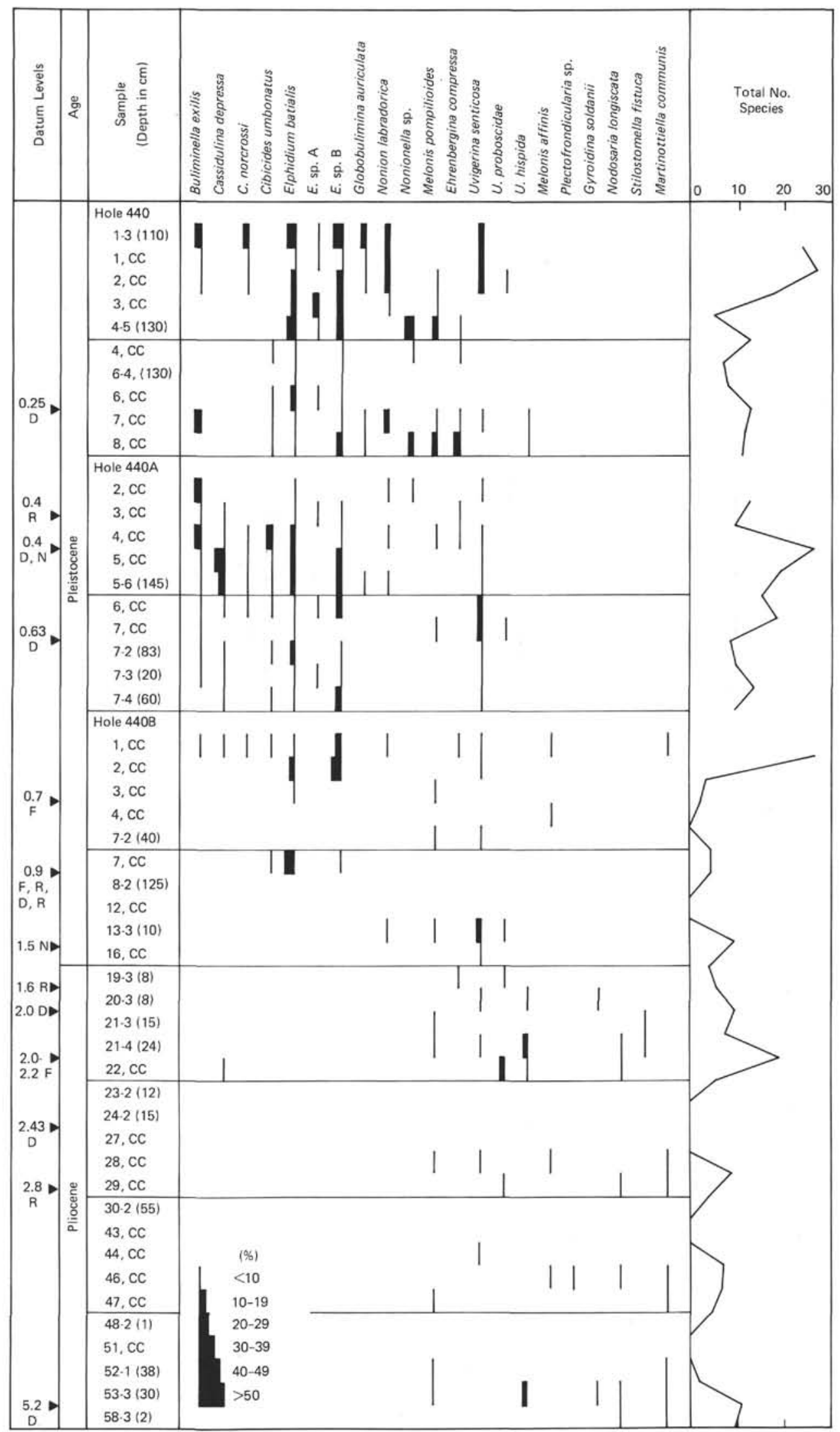

Figure 5. Range and relative abundance of dominant benthic species and total number of species in Holes 440, 440A, and 440B. (D = diatom [Barron, this volume], $N=$ nannofossil [Shaffer, this volume], $R=$ radiolaria [Reynolds, this volume], $F=$ planktonic foraminifera [Keller, this volume].) 
cies. It is assumed that species resided within the same depth environment throughout their biostratigraphic range, and although such an assumption is in general valid, there are exceptions. For instance, until recently it had been assumed that all species of Elphidium inhabit shallow neritic environments; now we know that at least one late Pleistocene to Recent species of Elphidium ( $E$. batialis) lives in deep waters $(1000 \mathrm{~m}-2000 \mathrm{~m})$ in the Northwest Pacific (Matoba, 1976; Ishiwada, 1964; Saidova, 1961). Similar changes in depth range may have occurred in the past also. A further problem of interpretation derives from the fact that some species inhabit different depth ranges in different parts of the oceans, where they are influenced by changes in subsurface circulation and water mass properties. This is particularly true of the Japan Trench area, where water mass conditions are complicated by the mixing of the warm water Kuroshio and cold water Oyashio currents. In addition, it must be kept in mind that the reliability of bathymetric interpretation decreases downcore - that is, with increasing age because of an increase of species that are now extinct. Despite these problems bathymetric interpretations can be made with relative accuracy within a certain depth range provided dominant species of known depth range are used.

In the following discussion on paleobathymetric interpretation of Leg 57 sites, depth of deposition has been inferred from the dominant ( $>10$ per cent) species present. Downslope displacement is inferred from the presence of shallow-water $(<500 \mathrm{~m})$ species within deep-water (1500-2000 m) assemblages. The following publications on depth ranges of species have been used: Matoba (1976), Berggren et al. (1976), Saidova (1961), Ingle (in press), Ingle, et al. (in press).

The Upper Cretaceous to Pleistocene bathymetric history of the Japan Trench area has been interpreted from benthic foraminiferal assemblages recovered from Sites 438 and 439. (Site 440 has been omitted in this interpretation because of its deep-water location [4509 m].) These two sites have been chosen for their proximity they are $5 \mathrm{~km}$ apart - similar seismic profiles, similar water depths (1550 m and $1656 \mathrm{~m}$, respectively), and complementary biostratigraphic and faunal records spanning the Late Cretaceous to the late Tertiary. Species known to be living within a definite depth range are listed in Table 5 along with a schematic paleobathymetric interpretation of the faunal assemblages. In the following discussion paleobathymetry will be discussed in chronological order.

The Upper Cretaceous benthic foraminiferal assemblage (Table 5) recovered from the hard, dark, silicified claystone indicates a deep bathyal environment (Sliter, personal communication). The silicified claystone, interpreted to be a fine-grained turbidite, is also a characteristic deep-water deposit. Overlying an erosional surface of this unit is a thick conglomerate $(48 \mathrm{~m})$ consisting mainly of porphyritic dacite boulders and occasional clasts of the underlying Upper Cretaceous unit. This Cretaceous/Tertiary unconformity is well known from land sections in Japan (Ishiwada and Ogawa, 1976). The absence of marine fossils within the conglomerate leads us to speculate that formation of this unit may have been subaerial or in very shallow waters. This speculation gains some support from the benthic foraminiferal assemblages recovered in the overlying sandstone of uppermost Oligocene age (Table 5), which indicate that deposition occurred in a shallow $(<500 \mathrm{~m})$ shelf to upper bathyal environment. Indeed, abundance of Elphidium mabuttii, Cribroelphidium sp., Buccella sp. Cassiduli$n a$, and Epistominella danvillensis suggests that deposition may have been in shallow shelfal waters. The presence of abundant gastropods and pelecypods supports this interpretation. However, in conflict with this view is the presence of several arenaceous foraminifers such as Cyclammina and Reophax (Figure 4), which at present inhabit deep waters $(1500-2000 \mathrm{~m})$.

A fine-grained turbidite sequence containing an upper middle bathyal biofacies (Table 5) of lower Miocene age overlies the upper Oligocene sandstone and indicates a gradual subsidence of the sea floor. Diatom faunas indicate a hiatus during late early Miocene to middle Miocene (Barron, this volume). No foraminiferal data are available for the middle Miocene interval. By the late Miocene subsidence had reached lower bathyal $(>2000 \mathrm{~m}+)$ depth. Pliocene to Pleistocene benthic assemblages indicate that gradual shallowing occurred from lower bathyal to lower middle bathyal depth $(2000 \mathrm{~m}+-1500 \mathrm{~m})$ during this time.

\section{ACKNOWLEDGMENTS}

I would like to thank the scientists of Leg 57 for a stimulating scientific experience. Thanks also to Drs. Y. Matoba, W. Sliter, Y. Takayanagi, and S. Maiya for valuable discussions. I thank Drs. J. C. Ingle, Y. Matoba, and Y. Takayanagi for critically reviewing this manuscript. I gratefully acknowledge the U.S. Geological Survey at Menlo Park for the use of the Cambridge S-180 scanning electron microscope and am grateful to Mr. R. L. Oscarson for operating it. This work was partially supported by U.S. National Science Foundation Grant OCE 76-82181 CENOP.

\section{REFERENCES}

Asano, K., 1953a. Miocene Foraminifera from the Noto Peninsula, Ishikawa Prefecture. Short Papers, Inst. Geol. Paleont. Tohoku Univ., Sendai, Japan, 5, 1-21.

1953b. Oligocene Foraminifera from Utsunai, Tonbetsu-mura, North Hokkaido. Short Papers, Inst. Geol. Paleont. Tohoku Univ., Sendai, Japan, 5, 22-24. 1958. Some Paleogene Smaller Foraminifera from Japan, Science Reports of the Tohoku University, Sendai, Japan, Second Series (Geol.), 29, 43-76.

Bandy, O. L., 1953. Ecology and paleoecology of some California foraminifera. Part 1. The frequency distribution of Recent foraminifera off California. J. Paleont., 27 (No. 2), 161-182.

Berggren, W. A., Benson, R. H., Haq, B. U., Riedel, W. R., Sanfilippo, A., Schrader, H. J., and Tjalsma, R. C., 1976. The El Cuervo section (Andalusia, Spain): Micropaleontologic anatomy of an early late Miocene lower bathyal deposit. Mar. Micropaleont., 1, 195-247.

Cushman, J. A., and Gray, H. B., 1946. A foraminiferal fauna from the Pliocene of Timms Point, California. Cushman Lab. for Foraminiferal Research, Special Publication No. 19 , pp. 1-46. 
Douglas, R. G., 1973. Benthonic foraminiferal biostratigraphy in the Central North Pacific, Leg 17, Deep Sea Drilling Project. In Winterer, E. L., Ewing, J. I., et al., Init. Repts. DSDP, 17: Washington (U.S. Govt. Printing Office), 607-672.

Ingle, J. C., Jr., 1973. Neogene foraminifera from the Northeastern Pacific Ocean, Leg 18, Deep Sea Drilling Project. In Kulm, L. D., von Huene, R., et al., Init. Repts. DSDP, 18: Washington (U.S. Govt. Printing Office), 517-567. in press. Cenozoic Paleobathymetry and depositional history of selected sequences within the southern California Borderland, Bandy Memorial Volume, Allan Hancock Foundation.

Ingle, J. C., Jr., Keller, G., and Kolpack, R. J., in press. Benthic foraminiferal biofacies, sediments, and water masses of the Southern Peru-Chile Trench area, Southeastern Pacific Ocean. Micropaleontology.

Ishiwada, Y., 1964. Benthonic Foraminifera off the Pacific coast of Japan referred to biostratigraphy of the Kazusa Group. Geol. Survey of Japan Publ., Report No. 205, pp. $1-43$.

Ishiwada, Y., and Ogawa, K., 1976. Petroleum geology of offshore areas around the Japanese Islands. United Nations ESCAP, CCOP Tech. Bull., 10, 23-34.

Kleinpell, R. M., 1938, Miocene Stratigraphy of California: Tulsa (American Association of Petroleum Geologists), 448.

Loeblich, A. R., and Tappan, H., 1953. Studies in Arctic foraminifera. Smithsonian Miscell. Coll., 121 (No. 7), 149.

Mallory, S. V., 1959. Lower Tertiary Biostratigraphy of the California Coast Ranges: Tulsa (American Association of Petroleum Geologists), p. 416.

Martin, L., 1952. Some Pliocene Foraminifera from a portion of the Los Angeles Basin, California. Cushman Found. for Foraminiferal Research, 3 (Parts 3 and 4), 107-140.

Matoba, Y., 1967. Younger Cenozoic foraminiferal assemblages from the Choshi District, Chiba Prefecture. Science Reports of the Tohoku University, Sendai, Japan, Second Series (Geol.), 38, (No. 2), 221-263.
1976. Recent Foraminiferal Assemblages off Sendai, Northeast Japan. First International Symposium on Benthonic Foraminifera of Continental Margins. Maritime Sediments Special Publication, 1, 205-220.

Pierce, R. L., 1956. Upper Miocene foraminifera and fish from the Los Angeles area, California. J. Paleont., 30 (No. 6), 1288-1314.

Saidova, Kh. M., 1961. Foraminiferal ecology and paleogeography, Far Eastern seas of the USSR and northwest part of the Pacific Ocean. Akad. Nauk SSSR, Inst. Okeanol., pp. $1-232$.

Schwager, C., 1867. Fossile Foraminiferen von Kar Nikobar. Novara: Exped. 1857-1859 (Vol. 2), Vienna, Part 2, Pal. Mitth., pp. 187-268.

Sliter, W. V., 1968. Upper Cretaceous Foraminifera from Southern California and northwestern Baja California, Mexico. The University of Kansas Paleontological Contr. Ser. No. 49., p. 1-141.

1978. Personal communication.

Sullivan, F. R., 1962. Foraminifera from the type section of the San Lorenzo Formation, Santa Cruz County, California. Univ. California Publ. in Geol. Sci., Berkeley, 37 (No. 4), 233-352.

Takayanagi, Y., 1960. Cretaceous foraminifera from Hokkaido, Japan. Science Reports of the Tohoku University, Sendai, Japan, Second Series (Geol.), 32 (No. 1), 154.

Uchio, T., 1960. Ecology of living Benthonic Foraminifera from the San Diego, California, area. Cushman Found. for Foraminiferal Research, Special Publication No. 5, pp. $1-46$.

Ujiie, H., Saito, T., Kent, D. V., Okada, H., Klein, G. deV., Koizumi, I., Harper, H. E., Jr., Thompson, P. R., and Sato, T. 1977. Biostratigraphy, paleomagnetism and sedimentology of late Cenozoic sediments in Northwestern Hokkaido. Japan. Bull. Nat. Sci. Museum, 3 (No. 2), 49-101.

White, W. R., 1956. Pliocene and Miocene foraminifera from the Capistrano Formation, Orange County, California. $J$. Paleont., 30 (No. 2), 237-260. 
TABLE 5

Bathymetric Distribution of Dominant Benthic Species at Sites 438 and 439 and Schematic Interpretation of Paleobathymetry

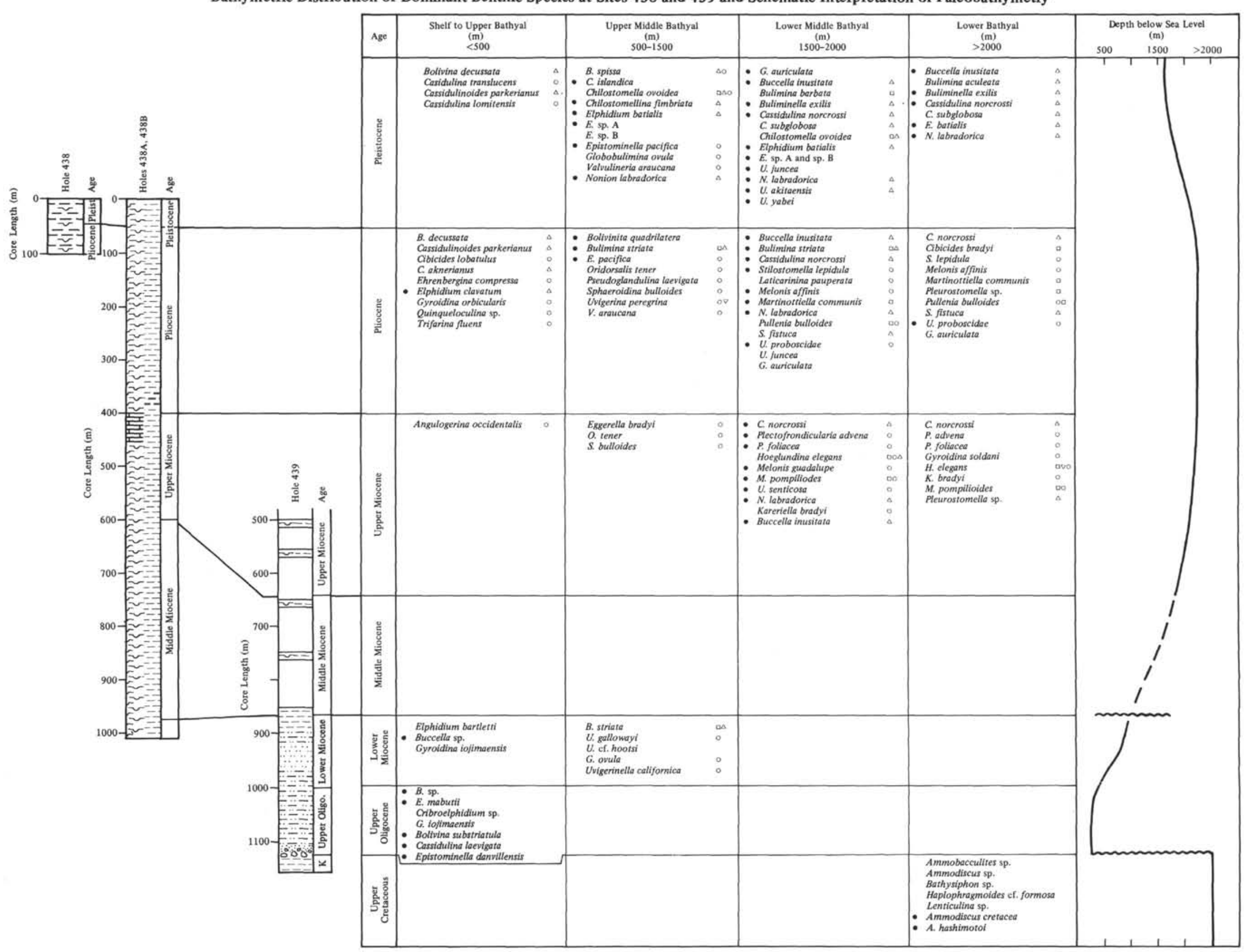


PLATE 1

(Bar represents $300 \mu \mathrm{m}$ for Figure 1;

bars represent $100 \mu \mathrm{m}$ for Figures 2-17.)

Figure $1 \quad$ Nodosaria vertebralis (Batsch). Sample 438A-7, CC. Upper Pliocene.

Figure 2 Dentalina subsoluta (Cushman). Sample 438A-12-1 $(20 \mathrm{~cm})$. Pliocene.

Figure 3 Dentalina frobisherensis Loeblich and Tappan. Sample 438A-12-1 $(20 \mathrm{~cm})$. Pliocene.

Figure 4 Stilostomella hayasakai (Ishizaki). Sample 438A-12-1 $(20 \mathrm{~cm})$. Pliocene.

Figure 5 Nodosaria holoserica Schwager. Sample 438A-11-2 $(29 \mathrm{~cm})$. Pliocene.

Figure 6 Stilostomella fistuca Schwager. Sample 438A-4, CC. Upper Pliocene.

Figure 7 Stilostomella lepidula (Schwager). Sample 438A-4, CC. Upper Pliocene.

Figure 8 Eggerella bradyi Cushman. Sample 438A-39,CC. Upper Miocene.

Figure 9 Kareriella bradyi Cushman. Sample 438A-12-1 (20 $\mathrm{cm})$. Pliocene.

Figure 10 Kareriella bradyi Cushman. Sample 438A-38,CC. Upper Miocene.

Figure 11 Plectofrondicularia foliacea (Schwager). Sample 438A-4,CC. Upper Pliocene.

Figure 12 Martinottiella communis (d'Orbigny). Sample 438A-7, CC. Upper Pliocene.

Figure 13 Plectofrondicularia advena (Cushman). Sample 438A-4,CC. Upper Pliocene.

Figure 14 Bolivinita quadrilatera (Schwager). Sample 438A-4, CC. Upper Pliocene.

Figure 15 Buliminella exilis Brady. Sample 438-1-2 (115 cm). Upper Pleistocene.

Figure 16 Bulimina aculeata d'Orbigny. Sample 438-2-4 (70 $\mathrm{cm})$. Upper Pleistocene.

Figure 17 Bulimina barbata Cushman. Sample 438A-38,CC. Upper Miocene. 
PLATE 1
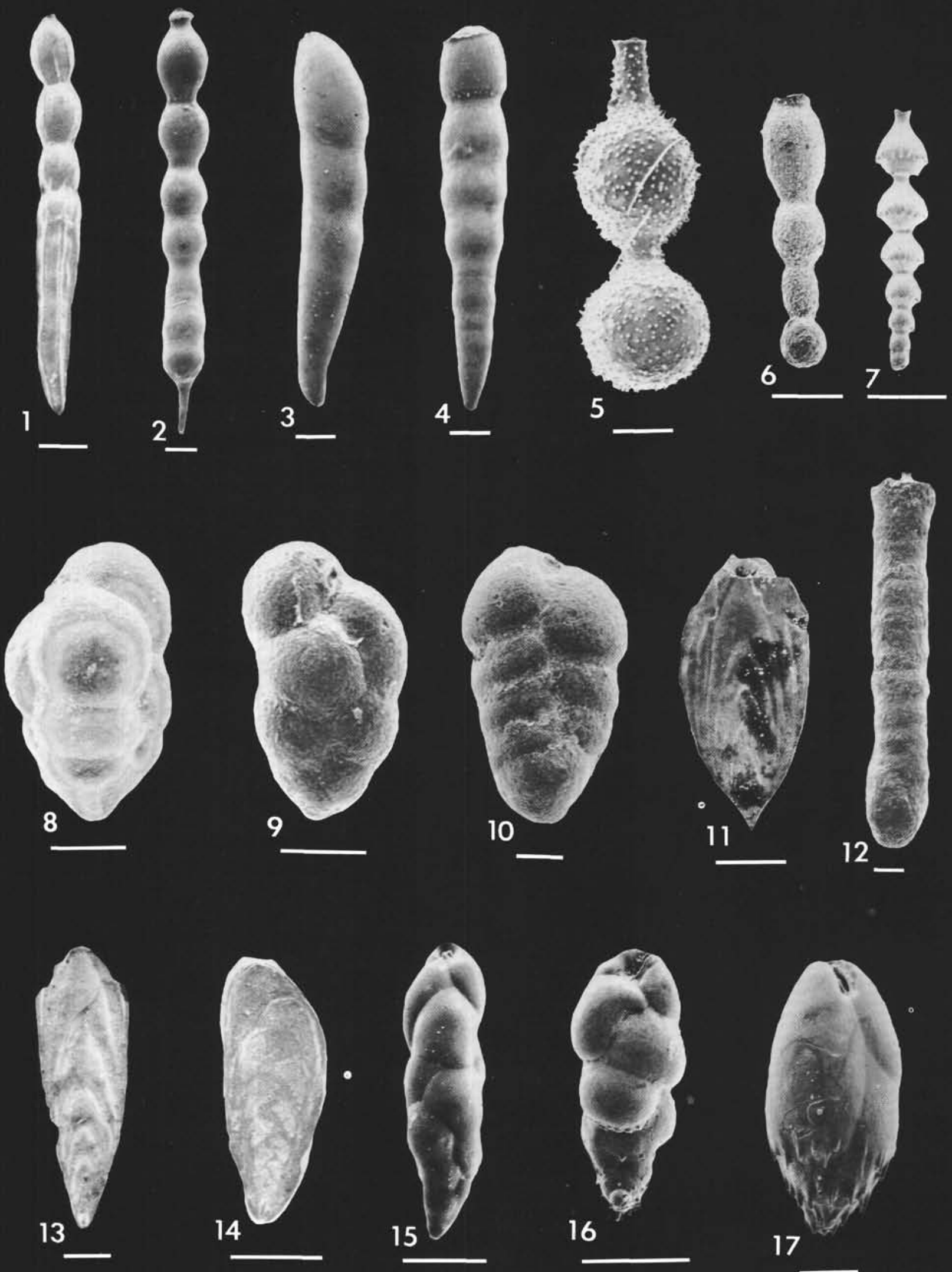


\section{PLATE 2}

(Bars represent $100 \mu \mathrm{m}$ for all figures except 10 and 11 , where bars represent $50 \mu \mathrm{m}$.)

Figure 1 Globobulimina auriculata (Bailey). Sample 438-1-2 $(115 \mathrm{~cm})$. Upper Pleistocene.

Figure 2 Bulimina striata d'Orbigny. Sample 438A-11-2 (29 $\mathrm{cm})$. Pliocene.

Figure 3 Laticarinina pauperata (Parker and Jones). Sample 438A-11-2 $(29 \mathrm{~cm})$. Pliocene.

Figure 4 Ehrenbergina compressa Cushman. Sample 438A11-2 $(29 \mathrm{~cm})$. Pliocene.

Figure $5 \quad$ Valvulineria araucana (d'Orbigny). Sample 438A-4, CC. Upper Pliocene.

Figures 6, 7 Chilostomellina fimbriata Cushman. Sample 4382-4 $(70 \mathrm{~cm})$. Upper Pleistocene.

Figures 8, 9 Cassidulina norcrossi Cushman. Sample 438-2-4 $(70 \mathrm{~cm})$. Upper Pleistocene.

Figures 10, 11 Cassidulina islandica Norvang. Sample 438-1-2 $(115 \mathrm{~cm})$. Upper Pleistocene.

Figure 12 Planulina wuellerstorfi (Schwager). Sample 438A-8, CC. Upper Pliocene.

Figure 13 Cassidulinoides parkerianus (Brady). Sample 4382-7 $(70 \mathrm{~cm})$. Upper Pleistocene.

Figures 14-16 Gyroidina lamarkiana (d'Orbigny). Sample 438A-8, CC. Upper Pliocene. 

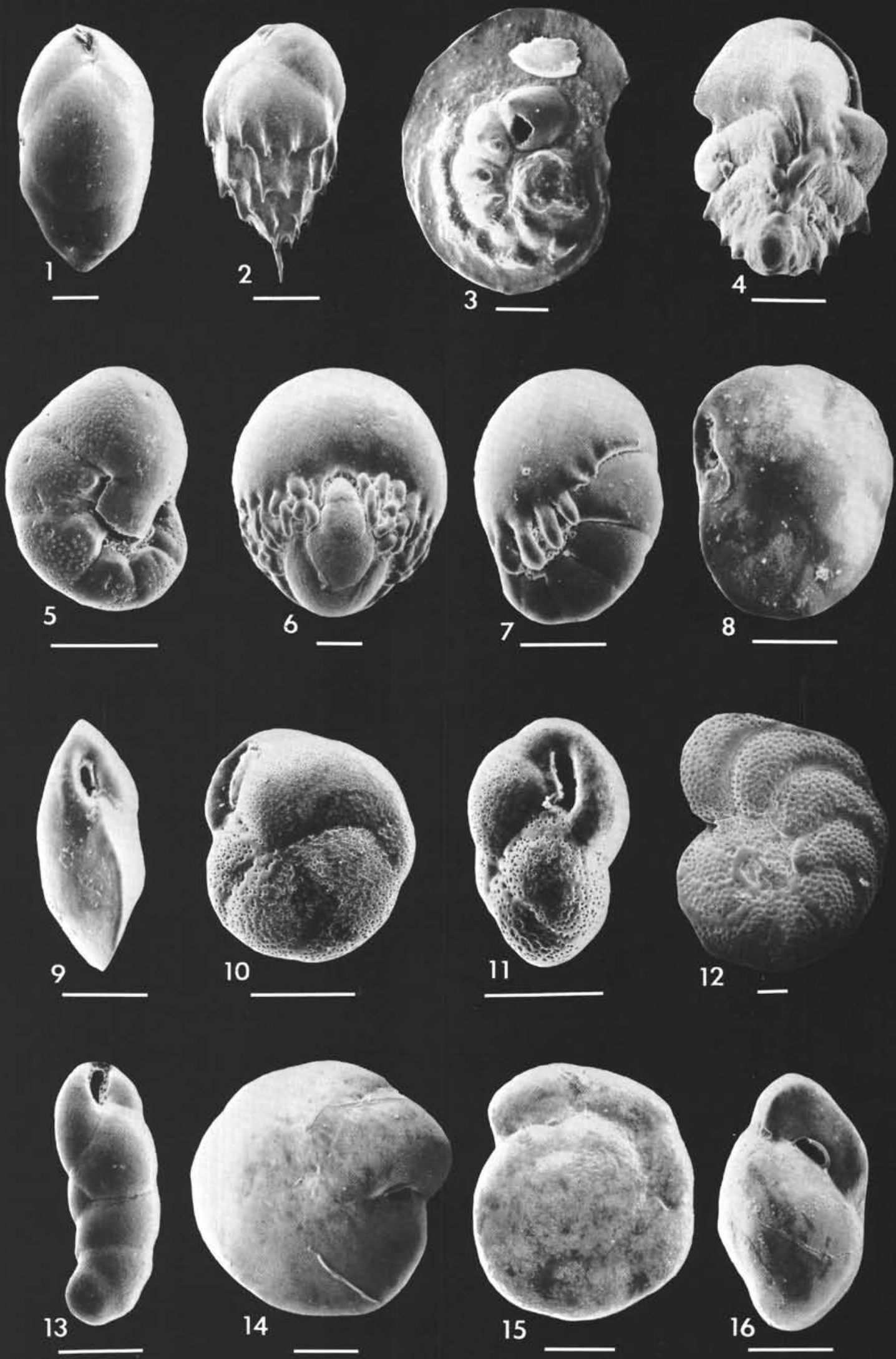
PLATE 3

(Bar represents $100 \mu \mathrm{m}$ for all figures except 15 and 16, where bar represents $50 \mu \mathrm{m}$.)

Figures 1-3 Buccella inusitata Andersen. Sample 438A-8,CC. Upper Pliocene.

Figures 4-6 Epistominella pacifica (Cushman). Sample 4381-2 (115 cm). Upper Pleistocene.

Figures 7, $8 \quad$ Nonionella sp. Sample 440-4-5 (130 cm). Upper Pleistocene.

Figures 9, $10 \quad$ Nonion labradoricum (Dawson).

9. Sample 438A-11-2 $(29 \mathrm{~cm})$. Pliocene.

10. Sample 438-1-2 $(115 \mathrm{~cm})$. Upper Pleistocene.

Figures 11, 12 Melonis pompilioides (Fichtel and Moll). Sample 438A-7,CC. Upper Pliocene.

Figure 13 Melonis affinis (Reuss). Sample 438-3-4 (43 cm). Pleistocene.

Figure 14 Elphidium clavatum (Cushman). Sample 438A5-3 $(61 \mathrm{~cm})$. Upper Pliocene.

Figures 15, 16 Elphidium subincertum Asano. Sample 438-2-4 $(70 \mathrm{~cm})$. Upper Pleistocene. 
PLATE 3
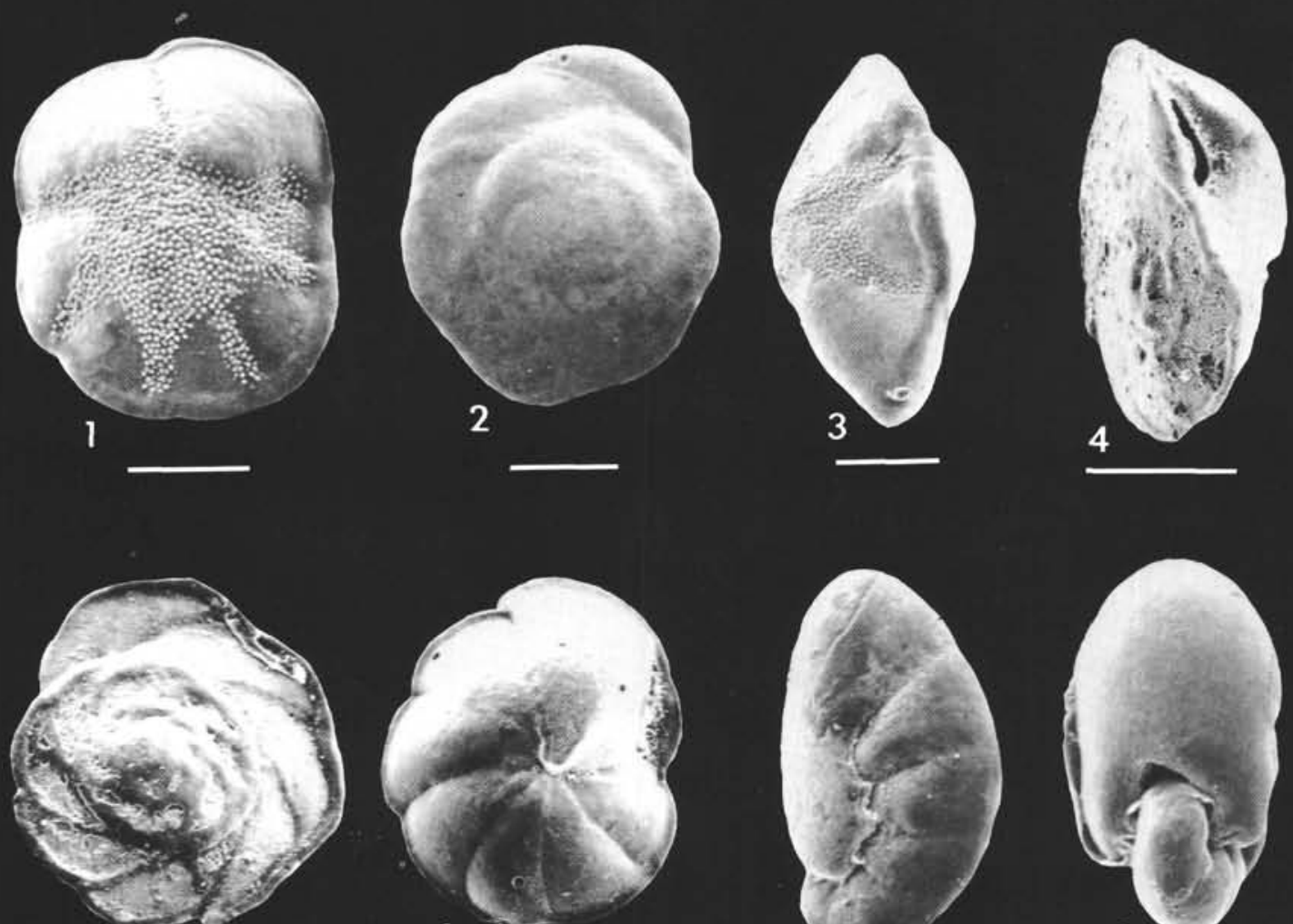

5
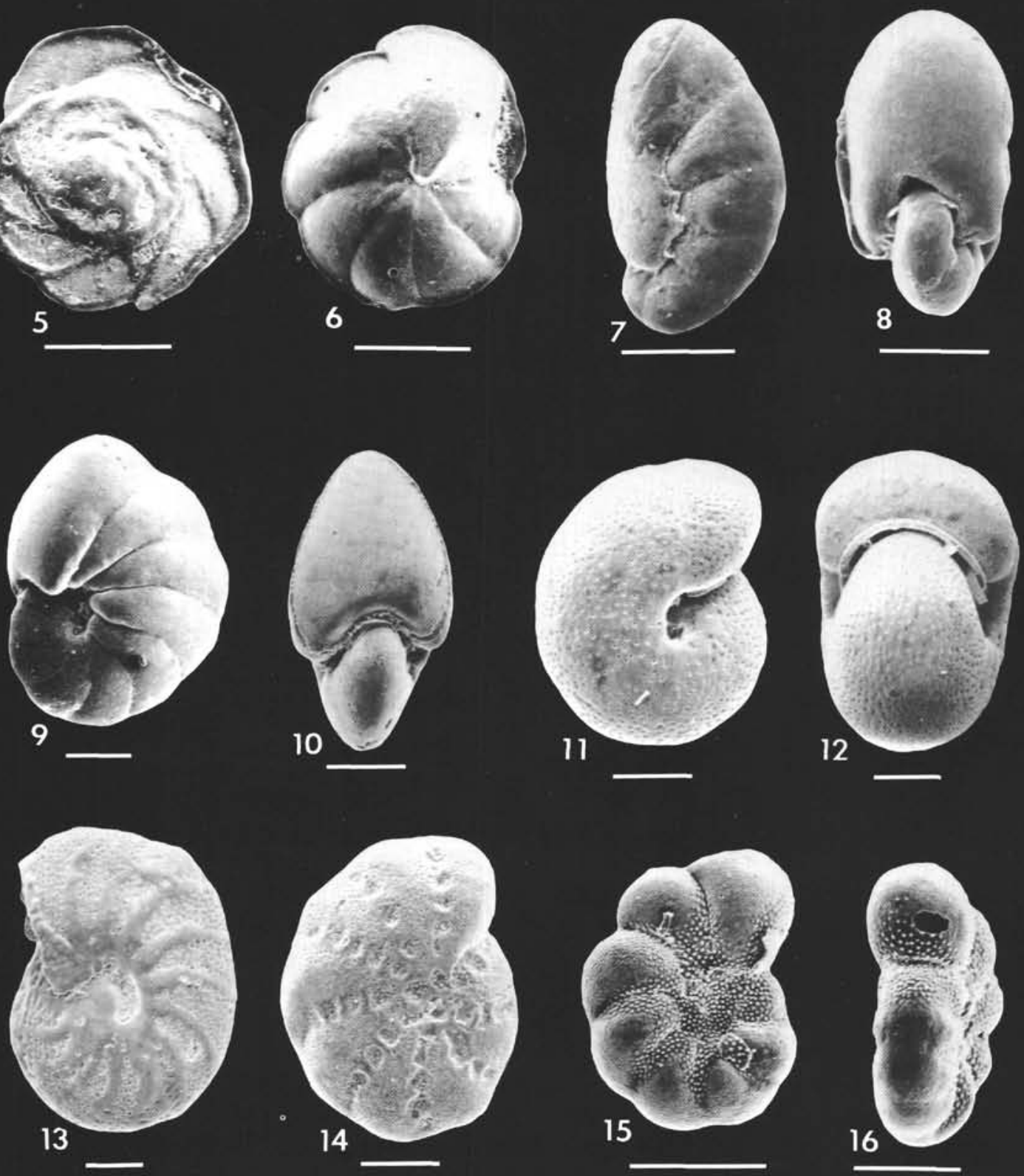
PLATE 4

(Bar represents $100 \mu \mathrm{m}$.)

Figures 1-3 Elphidium sp. A. Sample 438-2-4 (70 cm). Upper Pleistocene.

Figure 4 Elphidium batialis Saidova. Sample 438-4,CC. Upper Pleistocene.

Figures 5-7 Elphidium sp. B. Sample 438-3-4 (43 cm). Upper Pleistocene.

Figure $8 \quad$ Elphidium batialis Saidova. Sample 438-3-2 (28 $\mathrm{cm})$. Upper Pleistocene.

Figures 9, 10 Uvigerina akitaensis Asano. Sample 438-1-2 (115 $\mathrm{cm})$. Upper Pleistocene.

Figures 11, 12 Uvigerina yabei Asano.

11. Sample 438-3-2 $(28 \mathrm{~cm})$. Upper Pleistocene.

12. Sample 438-1-2 $(115 \mathrm{~cm})$. Upper Pleistocene.

Figure 13 Uvigerina cf. yabei Asano. Sample 438-1-2 (115 $\mathrm{cm})$. Upper Pleistocene. 


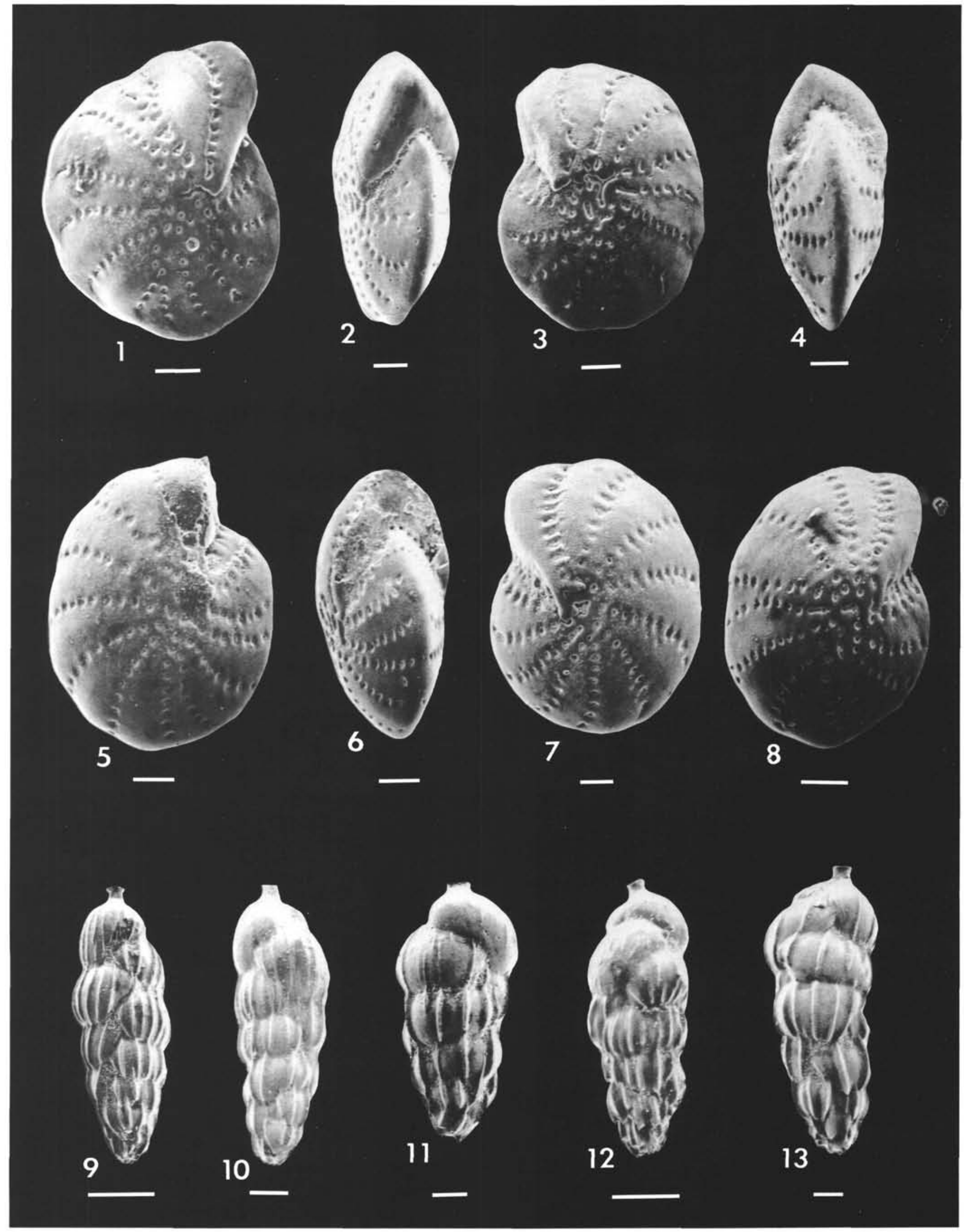


PLATE 5

(Bar represents $100 \mu \mathrm{m}$.)

Figure 1 Uvigerina yabei Asano? Sample 438-1-2 $(115 \mathrm{~cm})$. Upper Pleistocene.

Figure 2 Uvigerina peregrina dirupta Todd. Sample 438A5-3 $(61 \mathrm{~cm})$. Upper Pliocene.

Figures 3-5 Uvigerina juncea Cushman and Todd. Sample 438-2-4 $(70 \mathrm{~cm}), 438-3-2(28 \mathrm{~cm})$. Upper Pleistocene?

Figures 6-8 Uvigerina senticosa Cushman. Sample 438-2-4 (70 $\mathrm{cm}), 438-3-2(28 \mathrm{~cm})$. Upper Pleistocene?

Figures 9, 10 Angulogerina occidentalis (Cushman). Sample 438A-39,CC. Upper Miocene.

Figures 11, 12 Uvigerina proboscidae Schwager. Sample 438A-38, CC. Upper Miocene.

Figure 13 Uvigerina sp. Sample 439-13,CC. Lower Miocene.

Figure $14 \quad$ Uvigerina $\mathrm{cf}$. hootsi Rankin. Sample 439-15,CC. Lower Miocene. 

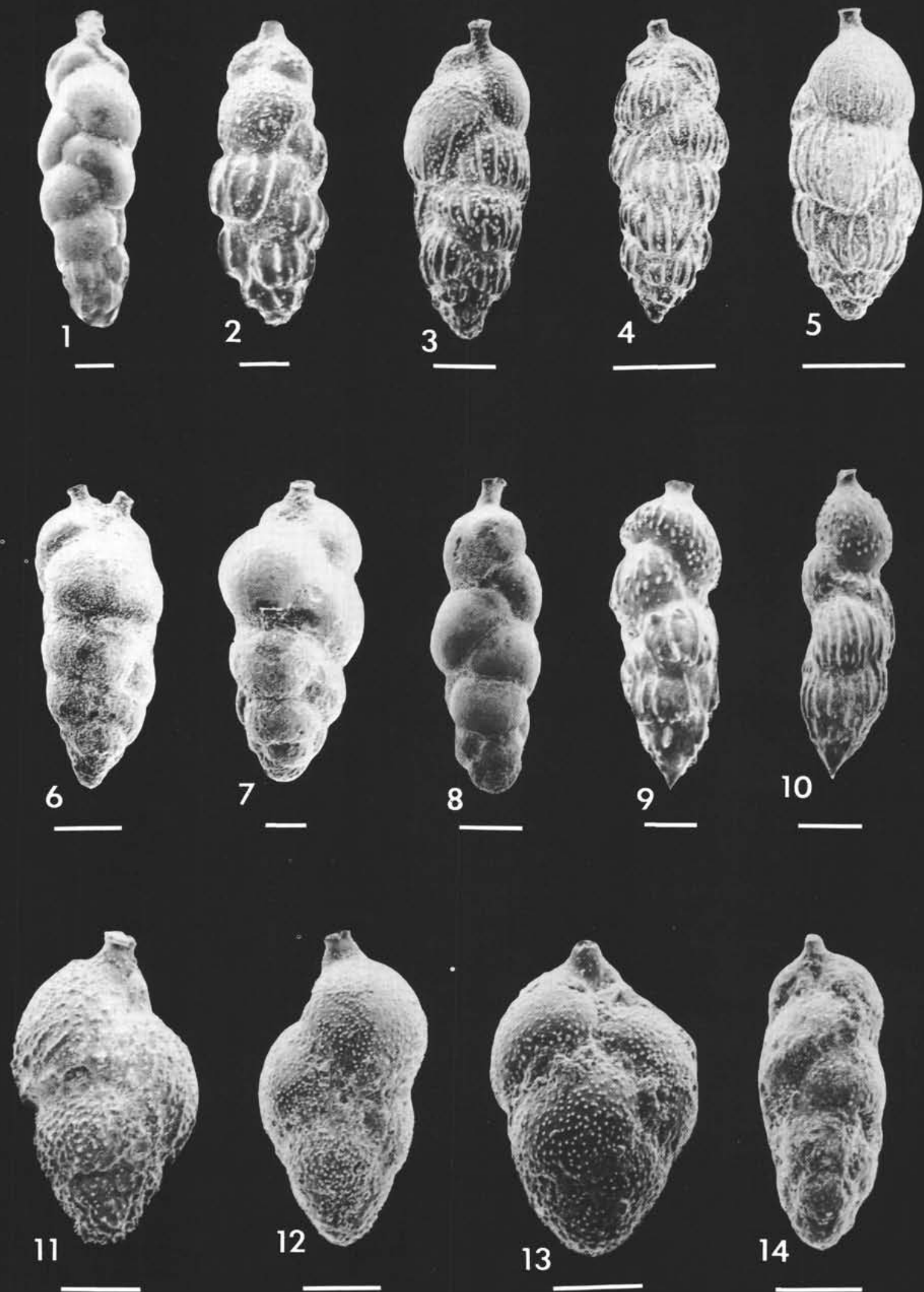
PLATE 6

(Bar represents $100 \mu \mathrm{m}$ for all figures, except 7 and 8, where bar represents $30 \mu \mathrm{m}$.)

Figure 1 Bolivina substriatula Asano. Sample 439-24,CC. Upper Oligocene.

Figures 2-4 Elphidium iojimaensis Asano and Murata. Sample 439-22-3 $(117 \mathrm{~cm})$. Upper Oligocene.

Figures 5, 6 Cribroelphidium sp. Sample 439-22-3 (117 cm). Upper Oligocene.

Figures 7,8 Epistominella danvillensis Howe and Wallace. Sample 439-24,CC. Upper Oligocene.

Figures 9, 10 Ammodiscus ( $=$ ? Spirillina) cretacea (Reuss). Samples 439-38-1 (20-30 cm), 439-39-1 (10-50 $\mathrm{cm})$. Upper Cretaceous?

Figure 11 Ammodiscus (= ? Spirillina) hashimotoi Takayanagi. Sample 439-39-1 (10-50 cm). Upper Cretaceous. 

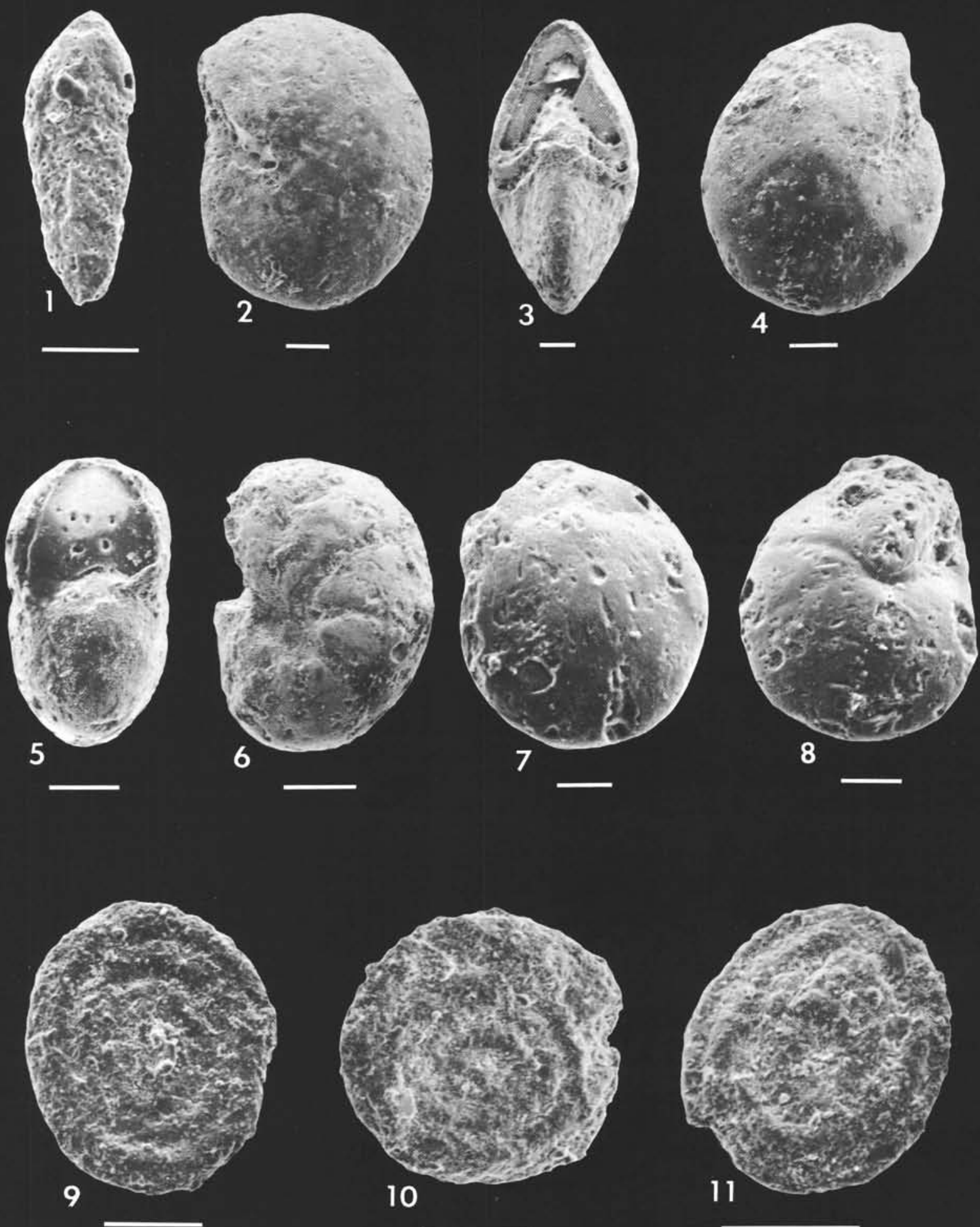